\title{
Biogeographic Patterns of Finnish Crane Flies (Diptera, Tipuloidea)
}

\author{
Jukka Salmela \\ Zoological Museum, Department of Biology, University of Turku, 20014 Turku, Finland
}

Correspondence should be addressed to Jukka Salmela, jueesal@utu.fi

Received 27 April 2012; Revised 25 July 2012; Accepted 14 August 2012

Academic Editor: David Roubik

Copyright () 2012 Jukka Salmela. This is an open access article distributed under the Creative Commons Attribution License, which permits unrestricted use, distribution, and reproduction in any medium, provided the original work is properly cited.

\begin{abstract}
Species richness of terrestrial and freshwater biota generally decreases with increasing latitude. Some taxa, however, show an anomalous species richness pattern in a regional or global scale. The aim of this study was to examine (i) regional variation in species richness, (ii) faunistic composition, (iii) occupancy, and (iv) proportions of different distribution types of Finnish crane flies. Analyses were based on incidence data pooled into 20 biogeographical provinces. Finnish crane fly fauna consists of 335 species; the provincial richness varies from 91 to 237. The species richness of all species and saproxylic/fungivorous species decreased with increasing latitude; mire-dwelling crane flies displayed a reversed pattern (Spearman's correlations). Thirty-one species occupied a single province and 11 species were present in all provinces. Provincial assemblages showed a strong latitudinal gradient (NMS ordination) and faunistic distance increased with increasing geographical distance (Mantel test). Nearly half (48\%) of the Finnish crane flies are Trans-Palaearctic, roughly one-third (34\%) are West Palaearctic, and only 16 and 2\% are Holarctic and Fennoscandian, respectively. Endemic Fennoscandian species are discussed in detail; most likely there are no true endemic crane flies in this region.
\end{abstract}

\section{Introduction}

1.1. Species Richness Gradient. In general, species richness decreases with increasing latitude. The tropics harbor far more animal and plant species than temperate or arctic zones (e.g., [1-3]). The most probable explanations for this pattern are related to productivity and biomass that are determined by the amount of available energy (sun light) and evapotranspiration (moisture) $[4,5]$. Moreover, historical factors such as glaciations have shaped local flora and fauna: retreating and advancing glaciers during the Pleistocene totally eradicated fauna and flora from most high latitude areas, while the tropics probably experienced less severe climatic stress [6]. In addition, the tropics have the largest geographical land area, and larger areas invariably support more species than smaller areas $[7,8]$. In smaller spatial scales, isolation, interspecific interactions, disturbance, and environmental heterogeneity also influence species richness (e.g., [9]).

Despite the preponderance of the general trend, some taxa show a reversed latitudinal pattern in species richness. For example, sawflies [10] and aphids [11] are richer in species in the north boreal and temperate zones than in the tropics. Within northwestern Europe (Fennoscandia, that is, Nordic countries, Russian Karelia, and Kola peninsula), species richness of stone flies [12,13], waders [14], and miredwelling bird communities $[15,16]$ increases with increasing latitude. It is hypothesized that availability of resources best explains the reversed patterns. For instance, environmental complexity, total area of flark fens, and abundance of invertebrate food explain the high species richness of mire-dwelling birds and waders in north Fennoscandia $[14,16]$. In a similar vein, exceptional diversity and abundance of Salix species, the most important food plant for sawfly larvae, account for the reversed pattern of sawfly richness [10, 17]. Parasitoid ichneumonid wasps have long been assumed to have the highest species richness in midlatitudes (e.g., $[18,19])$, but this notion is likely an artifact due to the poor sampling and premature taxonomy of the superfamily [20-22].

1.2. Biogeography of Finland. Finland is geographically part of Fennoscandia, being located in northernmost Europe. Current Fennoscandian biota in general, and Finnish in 
TABLE 1: Finnish biogeographical provinces, their abbreviations and full names, locations, sizes, and number of Malaise trapping sites during the years 2000-2011.

\begin{tabular}{|c|c|c|c|c|c|}
\hline \multicolumn{2}{|r|}{ Provinces } & \multicolumn{2}{|c|}{ Coordinates $^{1}$} & \multirow{2}{*}{$\operatorname{Size}^{2}$} & \multirow{2}{*}{ Malaise } \\
\hline Abbr. & Name & $\mathrm{N}$ & E & & \\
\hline $\mathrm{Al}$ & Alandia & 6698 & 3107 & 1.5 & 19 \\
\hline $\mathrm{Ab}$ & Regio aboensis & 6714 & 3278 & 11.5 & 41 \\
\hline $\mathrm{N}$ & Nylandia & 6698 & 3385 & 8 & 16 \\
\hline $\mathrm{Ka}$ & Karelia australis & 6727 & 3505 & 3 & 0 \\
\hline St & Satakunta & 6841 & 3262 & 14.5 & 25 \\
\hline $\mathrm{Ta}$ & Tavastia australis & 6849 & 3357 & 25.5 & 24 \\
\hline Sa & Savonia australis & 6846 & 3547 & 22.5 & 2 \\
\hline $\mathrm{Oa}$ & Ostrobottnia australis & 6995 & 3267 & 14 & 35 \\
\hline $\mathrm{Tb}$ & Tavastia borealis & 6946 & 3410 & 19 & 28 \\
\hline $\mathrm{Sb}$ & Savonia borealis & 6983 & 3531 & 21 & 24 \\
\hline $\mathrm{Kb}$ & Karelia borealis & 6990 & 3642 & 24 & 28 \\
\hline $\mathrm{Om}$ & Ostrobottnia media & 7186 & 3404 & 25 & 3 \\
\hline Ok & Ostrobottnia kajanense & 7133 & 3570 & 24.5 & 12 \\
\hline Oba & Ostrobottnia borealis pars australis & 7244 & 3477 & 15 & 32 \\
\hline Obb & Ostrobottnia borealis pars borealis & 7388 & 3412 & 24.5 & 22 \\
\hline Ks & Regio kuusamoensis & 7327 & 3598 & 18 & 63 \\
\hline Lkoc & Lapponia kemensis pars occidentalis & 7514 & 3426 & 13 & 30 \\
\hline Lkor & Lapponia kemensis pars orientalis & 7532 & 3534 & 21 & 10 \\
\hline Le & Lapponia enontekiensis & 7636 & 3299 & 8.5 & 34 \\
\hline $\mathrm{Li}$ & Lapponia inariensis & 7708 & 3518 & 23 & 28 \\
\hline
\end{tabular}

${ }^{1}$ National coordinate system grid $27^{\circ} \mathrm{E} ; \mathrm{N}$ coordinate refers to the distance from the equator (in $\mathrm{km}$ ). Coordinates are given with an accuracy of one km and refer to the midpoints of the provinces. ${ }^{2} \times 1000 \mathrm{~km}^{2}$.

particular, is strongly influenced by the legacy of Pleistocene glaciations [23]. The latest glacial maximum (Weichselian) took place about 18000 years ago and only a small part of Fennoscandia was free of ice some 11000 years ago $[6,23]$. Based on the distribution of plant taxa [24], proportions of short-winged carabids (Coleoptera) [25, 26], and fossil evidence [27], it has been suggested that the highest mountain tops (nunataks) and islands along the Norwegian cost were free of ice and some taxa were able to "overwinter" there during the Weichselian maximum. However, within Finnish borders, all terrestrial biota must have colonized the area during the last circa 10000 years. Because of this recent origin of Finnish biota, endemic species (i.e., taxa only present in Fennoscandia and nowhere else) are exceptions (e.g., [28]). In general, Finnish biota could perhaps be classified into three different colonization groups. Firstly, European, or West Palaearctic, species currently present in Finland are descendants of populations from separated glacial refugia [29-31]. Secondly, in addition to southern biota, Finnish fauna has a strong taiga element, that is, boreal species of eastern origin, and thirdly, an arctic element, that is, circumpolar species (e.g., [32-35]).

Finland is part of the Holarctic biome called the boreal zone, that is, a belt of coniferous forests. Southernmost parts of the country are hemiboreal, with mixed broad-leaved and coniferous stands, whilst northernmost Finland is characterized by mountain birch (Betula pubescens ssp. czerepanovii) forests and treeless fells. Because of this latitudinal variation,
Finland is an optimal region for biogeographic studies. In addition, such large-scale studies are made possible by the long faunistic and floristic tradition practiced there. For over 100 years, Finnish fauna and flora have been mapped according to 21 biogeographical provinces (e.g., [36-38], Table 1, Figure 1). Despite the fact that the boundaries of the provinces follow historical and/or current Finnish political municipalities, occurrence data mapped as such has been successfully analyzed in several biogeographic studies (e.g., $[13,39])$. One of the advantages of provincial approach to biodiversity studies is that old data from the literature or museum specimens with inaccurate labeling can be taken into account. It allows one to examine large-scale trends in species richness and distribution of taxa, but finer scale variation will of course be hidden. To conclude, the composition and species richness of Finnish fauna and flora are mainly driven by latitudinal variation and local environmental factors [39-44]. The impact of latitude is not surprising, given the long, over $1100 \mathrm{~km}$, gradient from south to north. To some extent, plant assemblages reflect increase of continentality from western to northeastern Fennoscandia $[45,46]$, but among insects longitude is a poor biogeographic predictor in NW Europe [39].

1.3. Crane Flies (Diptera, Tipuloidea), Finnish Fauna Emphasized. Crane flies are very speciose and ecologically diverse. Over 15000 valid species are currently known, 3175 of these are from the Palaearctic region [47]. Most crane fly 


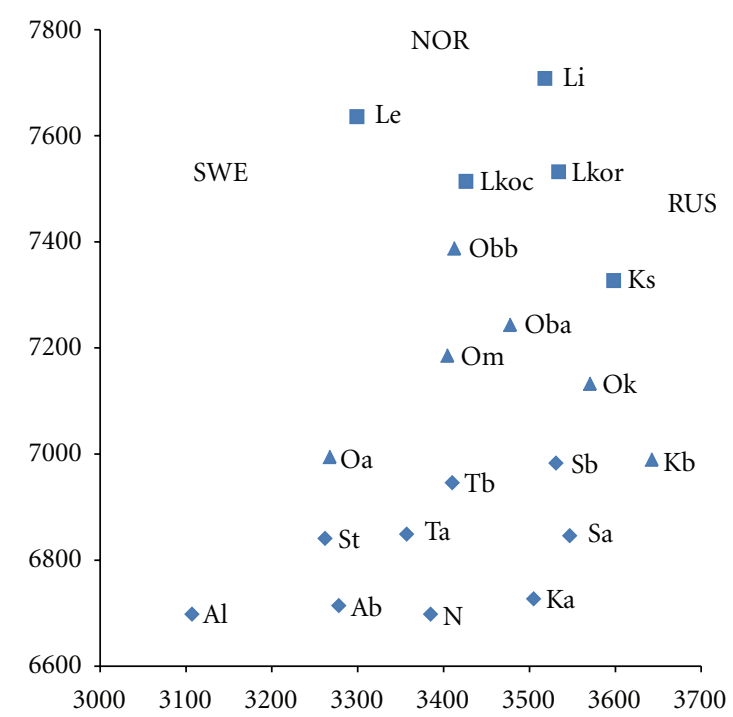

Figure 1: Schematic view of Finland, showing the location of biogeographical provinces (see Table 1 for abbreviations). Squares represent north boreal, triangels middle boreal and diamonds hemi and south boreal ecoregions. North co-ordinates are kilometers from the Equator. SWE = Sweden, NOR = Norway, RUS = Russia.

larvae prefer moist environments and eat detritus or prey upon other invertebrates [46]. There are also saproxylic, fungivorous, and herbivorous crane flies [48-50]. Adults are mainly short lived and have nonbiting mouthparts. Globally, the highest species richness of crane flies is encountered in the tropics and perhaps a notable number of tropical tipuloids still await their description. However, crane flies may occur abundantly in the boreal and arctic biomes [51], thus comprising an important component of food webs (e.g., [52]). The phylogeny of Tipuloidea is not yet fully resolved [53], but the monophyly of Tipulomorpha (Tipuloidea + Trichoceridae) in relation to other Diptera seems to be solid [54]. Most European authors follow Starý's [55] classification, that is, families Limoniidae, Tipulidae, Pediciidae, and Cylindrotomidae are recognized.

A short historical review of the Finnish crane fly taxonomy, ecology, and faunistics was provided by Salmela [56]. In short, Carl Lundström was the first who studied Finnish fauna seriously, roughly one hundred years ago. After that, Finnish crane flies were studied especially by Bernhard Mannheims (1950s-1960s) and Olavi Rautio (1980s). However, during those decades, the general faunistic and ecological knowledge remained poor. Spatially representative Malaise trapping and other sampling of adult crane flies performed during the years 2000-2011 have substantially improved knowledge on regional fauna ([57-63], Table 1). During the last 12 years, 53 species (16\% of the observed species richness) have been found for the first time from Finland and hundreds of new provincial records have been accumulated.

The aim of this paper is to examine patterns in species richness, assemblage composition, and occupancy of crane flies, based on data pooled into biogeographical provinces.
The bulk of this data is extracted from one of the largest Malaise trap samples ever collected (see Section 2). I also studied proportions of four main distribution types (TransPalaearctic, West Palaearctic, Holarctic, Fennoscandian) within ecoregions (hemi, and south boreal, middle boreal, and north boreal). Species richness patterns were examined for all species and for two ecological groups, mire-dwellers and saproxylic/fungivorous species.

\section{Material and Methods}

2.1. Study Area and Data Sets. Finland is located between $59^{\circ} 30^{\prime} \mathrm{N}$ and $70^{\circ} 05^{\prime} \mathrm{N}$ and $19^{\circ} 07^{\prime} \mathrm{E}$ and $31^{\circ} 35^{\prime} \mathrm{E}$, being part of the boreal zone, that is, zone of coniferous forests. Finland is divided into four major ecoregions or vegetation zones, namely, (from south to north) hemiboreal, south boreal, middle boreal, and north boreal and these zones are further divided into subzones (Figure 1). This zonation is mainly controlled by climate (e.g., decreasing mean annual temperature towards the north, differences in the length of the growing season, duration of snow cover, and continentality in a northeast-southwest gradient) and also topographic relief. Differences in vegetation structure between neighboring zones are not clear-cut but gradual changes take place along a latitudinal gradient (e.g., change of mire massif types from peat bogs to aapamires across the border of the southern and middle boreal regions). Finnish bedrock is mainly composed of acidic silicaceous rocks, intermediate (e.g., mica schist, amphibolite) or calcareous (marbles, dolomite) rocks are generally rare. For further information, see for example $[45,64,65]$.

A traditional way to map species' occurrences in Finland is to use biogeographical provinces (see, e.g., [37], Figure 1). There are a total of 21 such provinces, their surface areas range from 1500 to $25500 \mathrm{~km}^{2}$ (Table 1). In the present study, the very small province Kl (Karelia ladogensis) was merged to Sa (full names of the provinces are given in Table 1). Boundaries of the provinces mainly follow borderlines of Finnish municipalities and are thus administrative in nature. Because the provinces were unequal in size, the number of species in each province was corrected using formula:

$$
S_{\mathrm{cor}}=\frac{S_{\mathrm{obs}}}{A^{z}},
$$

where $S_{\text {cor }}$ is the corrected number of species, $S_{\text {obs }}$ the observed number of species in a province, $A$ is the area of a province, and $z$ is a constant taken from the species-area relationship ( 0.15 was chosen, see $[13,40])$.

Observed and corrected provincial species numbers were calculated for (i) all species, (ii) mire-dwelling species, and (iii) saproxylic/fungivorous species. Ombrotrophic bogs and poor-rich fens, mostly open or sparsely wooded, are the principal habitats for the mire-dwelling species as defined here. Spring-dwelling taxa were neglected, although most springs fall to mire types in Finnish mire ecology [65]. Some of the mire dwellers may also occur in swampy lake shores (such as Molophilus bihamatus, Prionocera turcica), but they are generally core species of peatlands. Subjective assessment 
is unavoidable here, but it is based on careful consideration by the author. Less subjective is the classification of crane flies into saproxylic/fungivorous species. Some genera are strictly fungivorous (e.g., Metalimnobia, Ula) or dependent on decaying wood (e.g., Gnophomyia, Lipsothrix) [66-68]. Classification of some species as saproxylic is based on the author's personal observations (Limnonia badia, Tipula pseudoirrorata, and T. stenostyla). Because some species are both saproxylic and fungivorous (i.e., larvae feeding on wood-decaying polyporous fungi), their combination here is justified. A total of 51 species were classified as mire dwellers and 42 as saproxylic/fungivorous (Table 6).

The occurrence of crane flies in Finnish provinces mainly follows Salmela [56]. However, after that publication, three species have been recorded as new for the regional fauna (Dicranomyia klefbecki, Ormosia hederae, and Tipula pauli), one species was described as new for science (Tipula recondita, [69]) and some provincial occurrences were added and corrected. The Finnish list of crane flies now consists of 335 species, of which only one (Tipula peliostigma, doubtful species) lacks provincial data (see [56]).

Biogeographical provinces were further classified into three groups, roughly corresponding to ecoregions or vegetation zones: (i) hemiboreal and south boreal ( $\mathrm{Al}, \mathrm{Ab}$, $\mathrm{N}, \mathrm{Ka}, \mathrm{Ta}, \mathrm{Tb}, \mathrm{Sa}, \mathrm{St}$, and $\mathrm{Sb}$ ), (ii) middle boreal (Oa, $\mathrm{Kb}, \mathrm{Ok}, \mathrm{Om}$, Oba, and Obb), and (iii) north boreal (Ks, Lkoc, Lkor, Le, Li). For each zone, (a) total species richness of crane flies, (b) number of species present in only one of the zones, (c) number of species present in all three zones, and (d) numbers of species representing four different distribution types were calculated. The distribution types used are Holarctic, Trans-Palaearctic, West Palaearctic, and Fennoscandian [47]. Holarctic species occur in both Nearctic and Palaearctic realms, Trans-Palaearctic species are recorded from both the eastern and the western part of the Palaearctic region, West Palaearctic species occur west of Ural mountains, and Fennoscandian species are not recorded outside Finland, Sweden, Norway, Kola Peninsula, and Russian Karelia. Further, numbers of crane flies that are absent from Central Europe (occurrence in the Baltic countries was allowed) were recorded for the three zones.

All available data dealing with the Tipuloidea fauna of Finland was compiled for the first time in 2006. Data from the literature, Finnish museum specimens, and the author's personal observations were entered into a database, which includes locality data and ecological information, if available. This database has since been updated and by the end of March 2012 it included 14782 entries for the families Limoniidae, Tipulidae, Pediciidae, and Cylindrotomidae (entry = data from a museum specimen or an observation from a single locality). Between the years 2000 and 2011, crane flies have been collected quite intensively in Finland, especially by Malaise traps and sweep netting. Most of this material has been collected by me, but also material collected by several other persons was identified and tabulated. In total, 476 Malaise trapping sites, circa 1670 Malaise trapping months, form the core of this new material; this collecting effort yielded 101081 crane fly specimens and 301 species and is perhaps the largest Malaise trapping so far performed.
One trap per locality was used in the majority of study sites, rarely three or more (maximum 15 traps in a study site). Malaise trapping was performed across a wide spatial scale, ranging from Aland Islands to the northernmost Finland (Table 1). Further, important material was collected from decaying trees using trunk-emergence traps (e.g., Halme et al. submitted ms). However, it must be stressed that some provinces are far better sampled than others (Table 1) and some habitats are rather well (headwater streams, and springs, northern aapamires), some rather poorly (meadows, shores of large rivers, and Baltic coastal meadows south of Oba) represented in the Malaise trapping material. In spite of that, collecting effort has not been substantially different in the south, middle, and north boreal zones and the variation in species richness and faunistic composition should reflect real phenomena, not artifacts due to differing sample sizes (see below for details).

2.2. Statistical Methods. The faunistic composition of provincial crane fly assemblages was examined using nonmetric multidimensional scaling (NMS) ordination. NMS is an ordination method, in which the original ranked distances (based on distance measure) of the sample units in the $p$-dimensional species space are forced to a reduced, $k$ dimensional ordination $[70,71]$. The Jaccard coefficient was used as a distance measure. Spearman's correlation coefficient was calculated between the ordination's coordinates of the provinces and latitudinal and longitudinal coordinates. McCune and Grace [71, pages 107-108] questioned whether it is appropriate to present $P$ values in this connection because coordinate points of the sampling units along the dimensions are not independent variables. By calculating correlation, however, it is possible to interpret the geographical variation of provincial assemblages.

The Mantel test was used to examine the relationship between the faunistic dissimilarity and the geographical distance of the provinces. The Mantel test is used to test the null hypothesis of no relationship between two distance matrices, that is, the test evaluates linear correlation between two distance matrices. Each matrix is calculated from a different set of variables, measured for the same sample units (here provinces) [70, 71]. The test value $\mathrm{rM}$ is analogous to the Pearson correlation coefficient (range -1 and 1). Statistical significance is calculated by permutation $(9000$ permutations were used). The Jaccard coefficient was used as a distance measure for crane flies and Euclidean distance for geographic coordinates of the provinces.

Occupancy of crane flies in the provinces was calculated (i.e. number of species present in one, two, three,.., 20 provinces). No statistical fitting of occupancy frequency distribution was applied (e.g., [72]), and the shape of the distribution was assessed based on visual examination.

In order to analyze relationship with latitude and species richness (observed and corrected richness, see above), Spearman's $\left(R_{S}\right)$ correlations were calculated. However, because observed species richness correlated positively with Malaise trapping effort $\left(R_{S}=0.54, P=0.014\right)$, a partial correlation was also applied. This method can be defined as the correlation of the residuals after regression on the controlling 
TABle 2: Observed and corrected species richness of crane flies (Diptera, Tipuloidea) in Finnish biogeographical provinces for all species, mire-dwellers, and saproxylic/fungivorous species.

\begin{tabular}{|c|c|c|c|c|c|c|}
\hline & \multicolumn{2}{|c|}{ All species } & \multicolumn{2}{|c|}{ Mire species } & \multicolumn{2}{|c|}{ Saproxylic species } \\
\hline & Observed & Corrected & Observed & Corrected & Observed & Corrected \\
\hline $\mathrm{Al}$ & 117 & 110.1 & 19 & 17.9 & 14 & 13.2 \\
\hline $\mathrm{Ab}$ & 237 & 164.3 & 30 & 20.8 & 31 & 21.5 \\
\hline $\mathrm{N}$ & 204 & 149.3 & 22 & 16.1 & 33 & 24.2 \\
\hline $\mathrm{Ka}$ & 95 & 80.6 & 10 & 8.5 & 13 & 11.0 \\
\hline St & 152 & 101.8 & 18 & 12.1 & 21 & 14.1 \\
\hline $\mathrm{Ta}$ & 230 & 141.5 & 30 & 18.5 & 35 & 21.5 \\
\hline $\mathrm{Sa}$ & 140 & 87.8 & 13 & 8.1 & 22 & 13.8 \\
\hline $\mathrm{Oa}$ & 162 & 109.0 & 26 & 17.5 & 20 & 13.5 \\
\hline $\mathrm{Tb}$ & 188 & 120.9 & 32 & 20.6 & 30 & 19.3 \\
\hline $\mathrm{Sb}$ & 176 & 111.5 & 29 & 18.4 & 28 & 17.7 \\
\hline $\mathrm{Kb}$ & 168 & 104.3 & 25 & 15.5 & 30 & 18.6 \\
\hline $\mathrm{Om}$ & 91 & 56.2 & 19 & 11.7 & 10 & 6.2 \\
\hline $\mathrm{Ok}$ & 139 & 86.0 & 23 & 14.2 & 26 & 16.1 \\
\hline Oba & 145 & 96.6 & 29 & 19.3 & 16 & 10.7 \\
\hline Obb & 120 & 74.3 & 32 & 19.8 & 16 & 9.9 \\
\hline Ks & 178 & 115.4 & 40 & 25.9 & 21 & 13.6 \\
\hline Lkoc & 160 & 108.9 & 44 & 29.9 & 22 & 15.0 \\
\hline Lkor & 95 & 60.2 & 32 & 20.3 & 7 & 4.4 \\
\hline Le & 127 & 92.1 & 34 & 24.7 & 10 & 7.3 \\
\hline $\mathrm{Li}$ & 136 & 85.0 & 34 & 21.2 & 13 & 8.1 \\
\hline
\end{tabular}

variable. In other words, correlation between observed species richness (all species, saproxylic/fungivorous species, and mire-dwellers species) and latitude was controlled for Malaise trapping effort. Furthermore, Malaise trapping effort was taken into account by using sample-based rarefaction. Malaise trapping sites were compiled to a single sites $\times$ species matrix and were arranged according to ecoregions. The aim of this analysis was to evaluate whether rarefaction, that is, a method to standardize trapping effort, yields similar results as raw species richness counts for the ecoregions. It was thus predicted that hemi- and south boreal ecoregions have the highest rarefied richness, followed by middle and north boreal regions. NMS, Mantel test, correlations, and rarefaction were computed using the program PAST 2.14 [73].

\section{Results}

Species richness of all species is the highest in the southern provinces $\mathrm{Ab}$, Ta, and N (237-204 spp., Table 2), and both observed and corrected species richness were in negative relation with latitude (Table 3 ). The correlation is statistically significant for corrected species richness and partial correlation between latitude and observed species richness (controlling for Malaise trapping effort) (Table 3). Saproxylic/fungivorous species richness also follows the same pattern as that of all species, but mire-dwellers species have a reversed species richness pattern, that is, increasing number of species with increasing latitude (Tables 2 and 3). A total of 31 species occupied a single province and 11 species
TABLE 3: Spearman's correlations between provincial species richness (observed and corrected) and latitude ( $\mathrm{N}$ coordinates of the provinces). Correlation coefficients and associated $P$ values are given for all species, mire-dwelling species, and saproxylic/fungivorous species. Partial correlation coefficients and $P$ values are given for observed species richness and latitude, controlling for per province Malaise trapping effort (see Table 1).

\begin{tabular}{lccccc}
\hline \multirow{2}{*}{ All species } & & $R_{S}$ & $P$ & Partial & $P$ \\
\hline \multirow{2}{*}{ Mire species } & Observed & -0.352 & 0.128 & -0.628 & 0.004 \\
& Corrected & -0.521 & 0.018 & & \\
\hline \multirow{2}{*}{ Saproxylic species } & Observed & 0.705 & 0.001 & 0.731 & $<0.001$ \\
& Corrected & 0.557 & 0.011 & & \\
\cline { 2 - 6 } & Observed & -0.522 & 0.018 & -0.646 & 0.003 \\
& Corrected & -0.614 & 0.004 & & \\
\hline
\end{tabular}

were present in all provinces (Figure 2); mean occupancy per species was 9.2 (SD 5.9). The obtained occupancy frequency distribution (Figure 2) resembles unimodal with a satellite mode.

NMS ordination (Figure 3) indicated that provincial crane fly assemblages are separating along a latitudinal gradient. Distribution of provinces along the first NMS axis is positively correlated with latitude $\left(R_{S}=0.904, P<\right.$ $0.0001)$, but neither the first nor the second axis is correlated with longitude $\left(R_{S}=0.354-0.099, P=0.125-0.677\right)$. In parallel to the NMS ordination, the faunistic similarity of the provinces decreases with increasing geographic distance (Mantel test $M_{R}=0.737, P<0.001$, Figure 4). Pairwise 


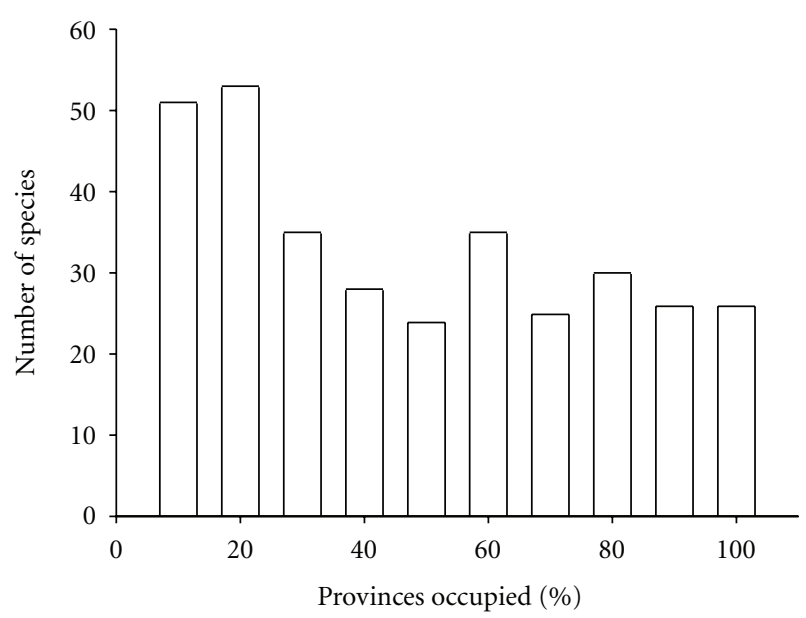

FIGURE 2: Occupancy frequency distribution of Finnish crane flies (Diptera, Tipuloidea, 334 spp.) in the biogeographical provinces $(n=20)$.

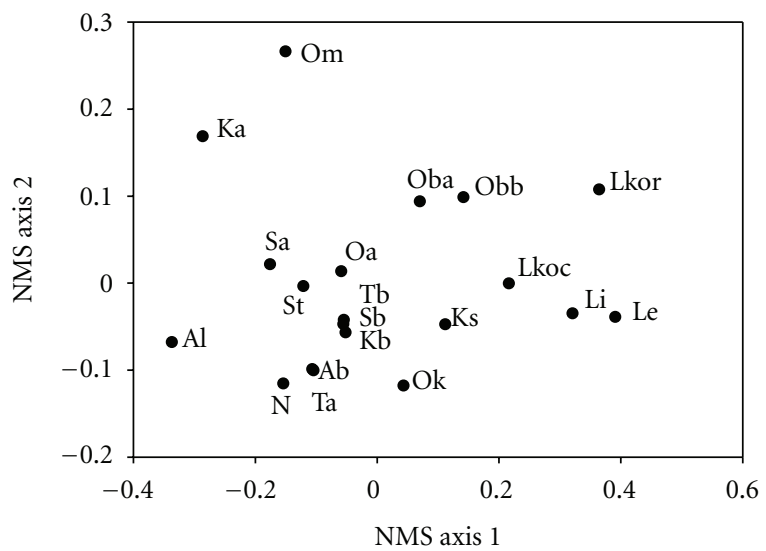

FIGURE 3: Two-dimensional NMS ordination of provincial (Diptera, Tipuloidea) crane fly assemblages (stress value 0.1105 ).

Jaccard distances ranged from $0.182(\mathrm{Ab}-\mathrm{Ta}$ ) to 0.786 (Le$\mathrm{Ka})$, the average being $0.54(\mathrm{SD} \pm 0.121)$.

Almost half (48\%) of the Finnish crane fly fauna is composed of wide-ranging, Trans-Palaearctic species (Table 4). Roughly one-third (34\%) of the species are West Palaearctic and only 16 and 2\% are Holarctic and Fennoscandian, respectively. Considering regional faunae (i.e., hemi- and south, middle, and north boreal), proportions of different distribution types remain roughly similar (Table 4 ). There is, however, a trend that the proportion of West Palaearctic species decreases from south to north. Correspondingly, the proportion of Holarctic and Trans-Palaearctic species increases from south to north (Table 4). The proportion of Fennoscandian species is low, roughly 1 or $2 \%$, in each zone.

Pooled species richness is the highest in the hemiand south boreal zone (278 spp.), being lower, but of similar magnitude in the middle boreal (244) and north boreal (235) zones (Figure 5). Based on rarefied Malaise trapping data, ecoregions are ranked similarly as raw species richness (Figure 6(a)). Rarefied richness at the level of 101

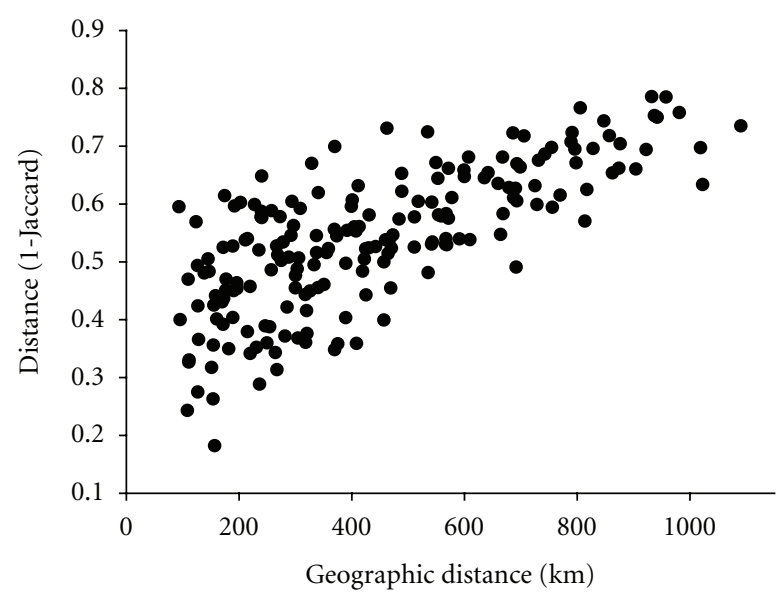

FIgURE 4: Correlation between provincial crane fly (Diptera, Tipuloidea), assemblage dissimilarity (1-Jaccard coefficient), and geographical distance $(\mathrm{km})$ of the provinces.

TABLE 4: Total numbers and proportions of different distribution types among crane flies (Diptera, Tipuloidea) in Finland and in the ecoregions (hemi and south boreal, middle boreal, and north boreal).

\begin{tabular}{lcccc}
\hline & FIN & $\begin{array}{c}\text { Hemi- and } \\
\text { south bor. }\end{array}$ & Middle bor. & North bor. \\
\hline HOL $^{1}$ & $54(16 \%)$ & $37(13 \%)$ & $40(16 \%)$ & $41(17 \%)$ \\
Tr-PAL $^{2}$ & $161(48 \%)$ & $137(49 \%)$ & $124(51 \%)$ & $124(53 \%)$ \\
W PAL $^{3}$ & $113(34 \%)$ & $102(37 \%)$ & $77(31 \%)$ & $65(28 \%)$ \\
FENSCA $^{4}$ & $6(2 \%)$ & $2(1 \%)$ & $3(1 \%)$ & $5(2 \%)$ \\
\hline
\end{tabular}

${ }^{1}$ Holarctic, ${ }^{2}$ Trans-Palaearctic, ${ }^{3}$ West Palaearctic, ${ }^{4}$ Fennoscandian.

trapping sites (the number of trap sites in the middle boreal ecoregion) is $220(\mathrm{SD} \pm 4.9)$ for the hemi- and south boreal region, $195(\mathrm{SD} \pm 4.8)$ and $186(\mathrm{SD} \pm 4.2)$ for the middle and north boreal zones, respectively. However, standard deviations of the two latter zones are overlapping, indicating similar level of species richness (Figure 6(b)).

The hemi- and south boreal zone harbors 45 species that are only recorded there, only six species are restricted to the middle boreal zone, and 30 species occur only in the north boreal zone. A total of 170 species are far ranging, known from all boreal zones within Finland. 56 (17\% out of total) Finnish crane fly species are absent from Central Europe and the number of such species clearly increases from the hemiand south boreal (20 spp.) to the north boreal zone (47 spp.) (Figure 5).

\section{Discussion}

4.1. Regional Species Richness and Its Variation. In general, the species richness and assemblage composition of Finnish crane flies correlated strongly with latitude, a result that is highly concordant with studies on other insects [41, 44], plants [40], and birds [74]. The diversity gradients are not explained by latitude itself, but environmental variables correlated with it [3]. In Fennoscandian scale, those variables 


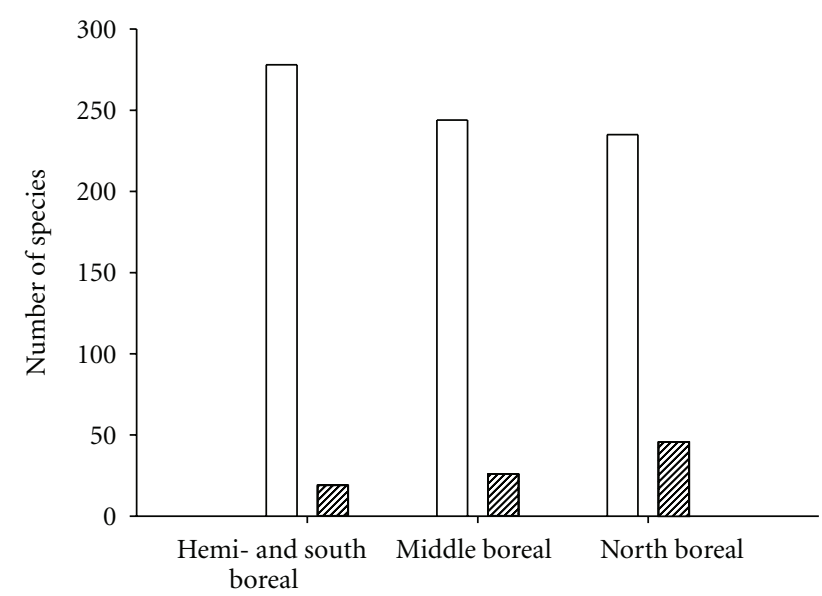

Figure 5: Pooled species richness (white bars) of crane flies (Diptera, Tipuloidea) and numbers of species not occurring in Central Europe (slashed bars) in the hemi- and south, middle, and north boreal zones. See the text for the delineation of the zones.

are mostly associated with climate [75-77], for example, length of growing season and monthly mean temperatures. In addition to climate, historical and ecological factors may also account for the observed patterns [75, 78]. Within vascular plants, for example, north of latitude $64^{\circ} \mathrm{N}$ the species richness of plants ceases to decrease; a potential explanation is the ancient, postglacial colonization of the land area from both northern and southern species pools [75]. Colonization in general is faster in favorable climatic conditions and slower in the ecological tolerance limits of a species [75]. Hence, at least some species, initially exapnding their ranges either from the south or the north, are now in their climatic equlibrium. It still must be stressed that recent range extensions of Finnish crane flies are unknown, because of the lack of long-term monitoring.

Firstly, I found that richness of all species and saproxylic/fungivorous species decreased with increasing latitude. Most species rich provinces lie in southwestern Finland $(\mathrm{Ab}, \mathrm{Ta}$, and $\mathrm{N})$, and most species poor in southern, central, and northern Finland (Ka, Om, and Lkor). With no doubt, this result is partly explained by unequal sampling efforts between the provinces: it is highly unlikely that neighboring provinces $\mathrm{N}$ and $\mathrm{Ka}$ differ almost 50\% in their species richness. There are differences in the recent provincial sampling efforts (Table 1), but there are also historical differences. Although there has been modest and nonsystematic sampling prior to the 2000s in Finland [56], some regions have gained more faunistic interest than others. For example, the southwestern part of the province $\mathrm{Ta}$ was sampled by T. Brander and others in the 1960s [79, 80] yielded numerous new records for that province. The northeastern province Ks also received special attention [81], as did $\mathrm{Li}$ [82]. The southern provinces $\mathrm{Ab}$ and $\mathrm{N}$ are the most densely populated in Finland and have also harbored most professional and amateur entomologists during past decades; even occasional collecting by these persons has accumulated the number of observed species in south Finland (see,

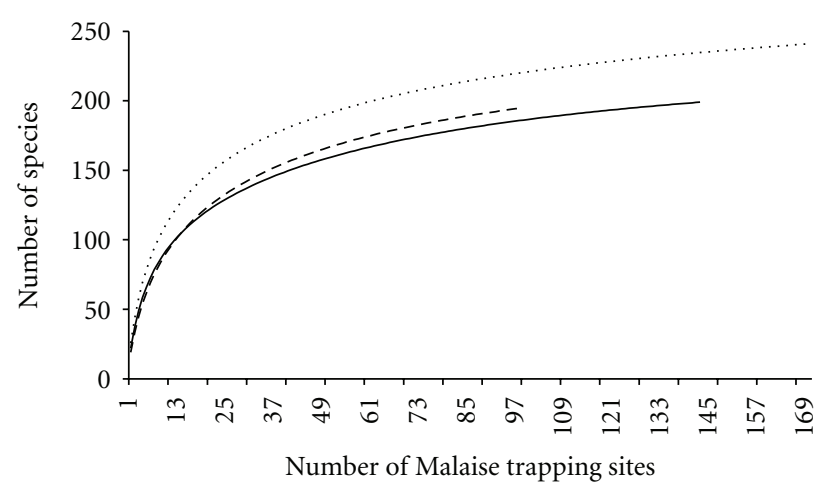

(a)

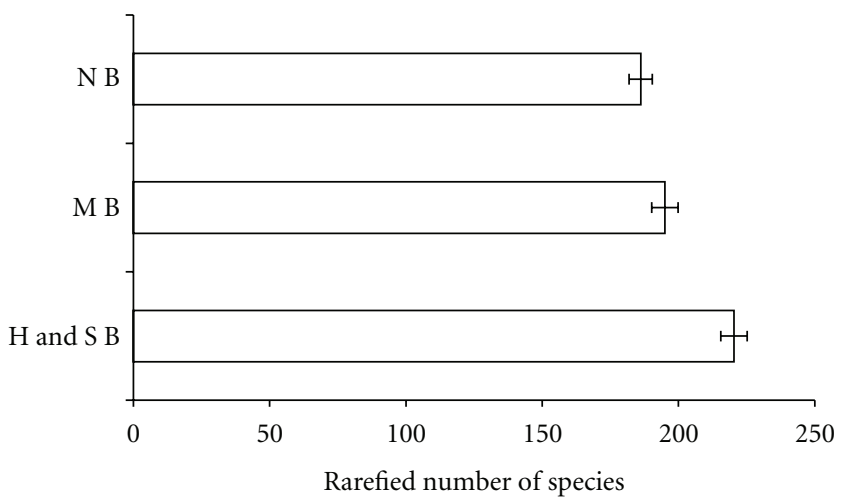

(b)

Figure 6: Rarefied regional species richness of Finnish crane flies (Diptera, Tipuloidea) based on Malaise trapping data (see Table 1), here arranged according to ecoregions. (a) Sample-based rarefaction curves, dot line $=$ hemi- and south boreal, dashed line $=$ middle boreal, and solid line $=$ north boreal. Standard deviations are not shown. (b) Rarefied species richness at the level of 101 traps, means, and SDs. $\mathrm{H}$ and S B = hemi- and south boreal, $\mathrm{M} \mathrm{B}=$ middle boreal, and $\mathrm{N} \mathrm{B}=$ north boreal ecoregion.

e.g., [83] for a bias in mapping data). However, regional differences in species richness are not solely explained by sampling artifacts. Local species richness is usually correlated with regional richness (type I relationship, [84]). That is, local assemblages embedded in species rich regions harbor more species than those in less diverse regions. Salmela [85] compared three sampling localities, which were considered the most species rich crane fly sites so far studied in southern and northern Finland. Those sites, headwater streams with similar sampling effort, were situated in the provinces $\mathrm{N}, \mathrm{Ta}$, and Li. Using raw data and individual-based rarefaction, it was noted that species richness was the highest in the south $(\mathrm{N}, \mathrm{Ta})$ and the lowest in the north $(\mathrm{Li})$. Even though the data set was small, this may be used as implicit evidence of the general latitudinal gradient. In parallel, sample-based rarefaction of the nation-wide Malaise trapping data also indicated the decrease in species richness from south to north, although middle boreal and north boreal ecoregions seemed to harbor similar level of rarefied species richness.

Considering saproxylic and fungivorous species, the observed pattern was expected since the number of tree 
species decreases toward the north (e.g., [45]). In northernmost Finland, large districts are treeless fells or mainly covered by one species, mountain birch, whereas there is a much richer assortment of deciduous and coniferous trees in southernmost Finland. It should be noted that some of the saproxylic crane flies, such as Elephantomyia edwardsi and Gnophomyia acheron, are confined to, or at least preferring, old-growth forests. Due to the human influence, such forests are rare especially in southern and western Finland, being isolated patches within a matrix of managed stands [64]. Reflecting this habitat degradation, many forestdwelling beetles have vanished from southern and western parts of the country [86]. Furthermore, restoration success, measured as numbers of pyrophilous and saproxylic species after prescribed burning, differs between eastern and western Finland [87]. Thus, regional differences in the management history of Finnish forests have already affected species' ranges, but there is no data to evaluate regional extinctions among forest-dwelling crane flies.

Secondly, even though a general decrease of provincial species numbers from south to north was observed, this decline is not very large. Pooling the provinces into three zones, roughly corresponding to the boreal ecoregions (Figure 4), an absolute difference of 43 species between hemi- and south boreal and north boreal zones was found. Furthermore, there is also a true turnover in the Finnish fauna; this is evidenced by the provincial assemblage variation (see below for further discussion) and also by the numbers of species restricted to respective zones. Over 40 species are truly southern, not occurring in the middle or north boreal zones, and 30 north boreal species display an opposite pattern. The middle boreal zone harbors few (6 spp.) species recorded only there, which implies that this zone is a mixture of northern and southern elements. In other words, there is true turnover, not just a gradient created by regional differences in alpha diversity (e.g., [88]).

Thirdly, there was a reversed latitudinal species richness pattern among mire-dwelling crane flies. A similar increase in species numbers has been observed among the avifauna of Finnish mires [16]. In general, Finland is a land of mires: about one-third of the land area was originally covered by peatlands [65]. Mires prevail in the Finnish landscape in central and northern Finland, especially in provinces such as Om, Oba, Lkoc, and Lkor [65]. Finnish mires can be roughly divided into two major types, ombrotrophic (raised bogs) and minerotrophic (aapamires, fens). The former are typical in the south boreal zone, the latter dominate in the middle and north boreal zones [65]. Compared to bogs, aapamires are rather heterogeneous in their surface patterns and vegetation. By definition, bogs receive only rain water and are thus poor in cations and characterized by low $\mathrm{pH}$ values. Aapamires vary from poor to rich fens and have diverse plant communities driven by $\mathrm{pH}$ and availability of nutrients [89]. Within aapamires, there is a tendency that shallow, inundated pools called flarks are more common in the north compared to the south $[16,65]$. The large surface area of flark fens in the north provides plentiful insect food for waders and other insectivorous birds [15], partly explaining the reversed gradient among peatland birds. It is likely that sheer area effect (total surface area of mires) and environmental heterogeneity (amount of flark fens, presence of calcareous bedrocks) account for the high species richness of mire-dwelling crane flies in the northern provinces. As with the forests discussed above, human impact on Finnish mires is higher in the south than in the north. About $60 \%$ of Finnish mires have been drained in order to improve timber growth, and most of the pristine or lightly affected mires lie in the north boreal zone [65]. In a nationwide scale, the importance of this large-scale deterioration in habitat quality and diminishing area is practically unknown for crane flies.

Fourthly, occupancy of crane fly species in the provinces was dominated by rare species, and the obtained occupancy frequency distribution resembles unimodal with a satellite mode [72]. However, no statistical distribution was fitted to the observed one. If an ad hoc threshold value close to $25 \%$ (quartile) is applied here (see [90]), 104 Finnish crane fly species are known from four or fewer provinces $(\leq 20 \%)$ and could be regarded as rare. On the other end, 52 species are common, known from 17 to 20 provinces.

4.2. Provincial Variation of Crane Fly Assemblages. Provincial crane fly assemblages were highly correlated with latitude. That is, crane fly assemblages differentiate along a southnorth gradient. This result is in accordance with the result that faunistic similarity decreases with increasing geographic distance. Based on visual inspection of the NMS ordination (Figure 3), there are no clear clusters of provinces; rather, we see a continuum-like faunal differentiation along the latitudinal gradient. It must be noted that the distance measure used, 1-Jaccard coefficient, is based on incidence data only. The pair-wise provincial similarities take no information on abundances of species, which may have effects to the results obtained [91]. I hypothesize that differences between provinces would be greater if abundance data had been used. For example, Tipula excisa is among the most numerous species in northernmost Finland, in $\mathrm{Li}$ and Le (e.g., [61]), becoming a low-abundance species south of the subalpine fell district. The range of this species extends as far south as Oba (the record from Oa is dubious, [56]) and, despite differences in abundance, the species has the same weight in all pair-wise calculations. However, good abundance data is hard to achieve [92], and such data for crane flies is far beyond the horizon. Even though I have Malaise trapping data that is spatially extensive, this trapping method seriously underestimates abundances of certain species (J. Salmela, unpublished).

The notion that provincial assemblages are greatly affected by latitude is not surprising $[39,76]$. As noted above (Sections 1 and 2), zonation of ecoregions is principally controlled by the climate. Along this climatic gradient habitats gradually change, partly explaining faunal differences. Perhaps more importantly, however, climate itself must play a crucial role as a determinant of species' ranges, regulating, for example, respiration and life cycles of ectothermic animals (e.g., [93]). Among Fennoscandian insects, longitude is a poor predictor of species composition [39], but it explains floristic composition better [40, 46]. 
Table 5: "Endemic" Fennoscandian crane fly (Diptera, Tipuloidea) species occurring in Finland, their current and predicted ranges and notes on taxonomic status of each species. See the text for details.

\begin{tabular}{lccc}
\hline & Occurrence & Taxonomy & True range \\
\hline Dicranomyia lulensis & FIN $^{1}, \mathrm{SWE}^{2}$ & OK & Palaearctic, boreal, and hemiarctic? \\
Limonia messaurea $m$. & FIN, SWE & OK, separate ssp. in the Russian Far East & Palaearctic, boreal? \\
Rhabdomastix parva & FIN, SWE, NOR ${ }^{3}$, ICE $^{4}$ & Parthenogenetic & Arctic? \\
Symplecta lindrothi & FIN, SWE & OK & Palaearctic, boreal, and temperate? \\
Tipula fendleri & FIN & Perhaps a syn. of T. nigrolamina & Boreo-montane, Trans-Palaearctic? \\
Cylindrotoma borealis & FIN, NOR, RKar ${ }^{5}$ & Perhaps intraspecific variation of C. distinctissima & Holarctic? \\
\hline
\end{tabular}

${ }^{1}$ Finland, ${ }^{2}$ Sweden, ${ }^{3}$ Norway, ${ }^{4}$ Iceland, ${ }^{5}$ Russian Karelia.

In this study, no significant correlations between ordination axes and longitude were found. However, in Fennoscandian scale, some species are indeed eastern taiga species and have not been found from Sweden or Norway (e.g. Phylidorea umbrarum, Gnophomyia acheron, and Tipula octomaculata). Western, or oceanic, crane fly species may be hard to be distinguished from southern species.

As discussed above, there is a turnover of crane fly species from south to north, not merely a decreasing number of species along this gradient. The observed patterns lead to the following predictions: (i) the composition of local communities is partly determined by latitude and (ii) local communities should be richer in species in the south than in the north (open bogs and fens showing opposite pattern). I refrain from delineating any biogeographic zones based on the occurrence of crane fly species, mainly due to the fact that the data used is perhaps not satisfactory (incidence, not abundance) for such purposes. It seems that invertebrate assemblages in Finland are rather different in the apices of the latitudinal gradient, but the transition of species composition is gradual, not strictly defined by vegetation zones $[13,44]$. However, despite the gradual change of species compositions, there seemingly are zones where biotic turnover is more pronounced than elsewhere $[74,94]$. As evidenced by diversity differentiation derived from Shannon-Wiener $\mathrm{H}^{\prime}$ index values of land birds $[74,94]$ and TWINSPAN classification of spring-dwelling aquatic macroinvertebrates [44], one such zone is on the border of middle and north boreal Finland. I leave it here open whether the border of middle and north boreal ecoregions is also an important transition zone for local crane fly assemblages. Nevertheless, it appears that the number of species not occurring in Central Europe is highest in the north boreal zone. Such species are generally circumpolar and eastern, having their origin in the arctic or boreal areas.

4.3. Distribution Types of Finnish Crane Flies. Almost half of the Finnish crane flies are Trans-Palaearctic species. Proportion of these species is the highest in the north boreal zone $(53 \%)$, the lowest in the hemi- and south boreal zone (49\%). The difference, however, is not drastic. This group of Trans-Palaearctic species contains crane flies that are ubiquitous and wide spread, such as Nephrotoma scurra [95]. On the other hand, there are also species such as Tipula kaisilai and Tipula subexcisa that are rare, disjunct species known from northern Fennoscandia and the mountains of the eastern Palaearctic region [47]. In general, due to the rather poor knowledge of crane flies outside Europe, the designation of species here as wide ranging does not refer to their area of occupancy, that is, the number of grid cells occupied, and thus Trans-Palaearctic (and Holarctic) species may be anything from common to rare.

Western Palaearctic species total about one-third (34\%) of the Finnish crane fly fauna, and the proportion of these species is clearly higher in the south (37\%) than in the north $(28 \%)$. It is very likely that species of European lowlands, that are mainly associated with deciduous broadleaved forests [96], are in Fennoscandia restricted by habitat and climate to the southern areas. Nevertheless, the group of western Palaearctic species also encompasses crane flies that are boreo-alpine or boreo-montane [97], that is, species not associated with nemoral forests (e.g., Tipula pallidicosta and T. cinereocincta). Holarctic species, covering $16 \%$ of the fauna, are chiefly northern species with a circumpolar range (e.g., Arctoconopa forcipata, Prionocera ringdahli). Some of the Holarctic species are "western arctic", that is, only known from the Nearctic region and Fennoscandia (e.g., Dicranomyia intricata, D. moniliformis). However, as noted above, not too much weight should be given to the current faunistic knowledge of crane flies, since occurrences of species are still poorly mapped. In addition, there may still be taxonomic problems and some presently Holarctic species may actually consist of separate species in the Nearctic and Palaearctic realms, or vice versa. According to Mikkola et al. [32], truly Holarctic noctuid species are mainly arctic (inhabitants of tundra) and species living in the taiga (boreal forests) are mainly Nearctic/Palaearctic species pairs. This pattern is apparently caused by the legacy of the last glaciation (Beringean refugia of Holarctic species) and an earlier (6 mya) split of Holarctic forests [32].

A small proportion, 2\%, of Finnish crane flies is Fennoscandian, that is, only known from Finland and/or neighboring areas (Norway, Sweden, Kola Peninsula, and Russian Karelia). These species are problematic, because Fennoscandia generally lacks endemic animal species. I will shortly discuss these species separately, given their potential historical and evolutionary interest (summarized in Table 5). Dicranomyia lulensis is known from northern Sweden and Finland [56]. The species may be locally abundant in swampy mires. The flying season is rather late, starting in mid-August 
TAble 6: List of Finnish crane fly (Diptera, Tipuloidea) species, supplied with information on regional and global range size. Saproxylic/fungivorous and mire-dwelling species are indicated. Nomenclature follows Oosterbroek [47].

\begin{tabular}{|c|c|c|c|c|c|c|c|}
\hline & \multicolumn{5}{|c|}{ Range } & \multirow[b]{2}{*}{$S x^{6}$} & \multirow[b]{2}{*}{$\mathrm{Mi}^{\top}$} \\
\hline & Prov. $^{1}$ & $\mathrm{FIN}^{2}$ & $\mathrm{Mal} \%{ }^{3}$ & Glob $^{4}$ & No C EUR ${ }^{5}$ & & \\
\hline \multicolumn{8}{|l|}{ Limoniidae } \\
\hline Achyrolimonia decemmaculata & 8 & $\mathrm{Sb}, \mathrm{Mb}$ & 0.5 & W PAL & & 1 & \\
\hline Adelphomyia punctum & 3 & $\mathrm{Sb}, \mathrm{Mb}$ & 1.2 & Tr-PAL & & & \\
\hline Antocha vitripennis & 4 & $\mathrm{Sb}, \mathrm{Mb}, \mathrm{Nb}$ & n.p. & Tr-PAL & & & \\
\hline Arctoconopa forcipata & 1 & $\mathrm{Nb}$ & n.p. & HOL & 1 & & \\
\hline A. obscuripes & 1 & $\mathrm{Nb}$ & n.p. & $\mathrm{HOL}$ & 1 & & \\
\hline A. zonata & 11 & $\mathrm{Sb}, \mathrm{Mb}, \mathrm{Nb}$ & 2.9 & Tr-PAL & & & \\
\hline Atypophthalmus inustus & 6 & $\mathrm{Sb}$ & 2.1 & Tr-PAL & & 1 & \\
\hline Austrolimnophila (Archilimnophila) harperi & 5 & $\mathrm{Mb}, \mathrm{Nb}$ & 1.9 & $\mathrm{HOL}$ & 1 & 1 & \\
\hline A. unica & 12 & $\mathrm{Sb}, \mathrm{Mb}, \mathrm{Nb}$ & 11.9 & $\mathrm{HOL}$ & & 1 & \\
\hline Cheilotrichia (Cheilotrichia) imbuta & 10 & $\mathrm{Sb}, \mathrm{Mb}, \mathrm{Nb}$ & 2.6 & Tr-PAL & & & \\
\hline C. (Empeda) areolata & 8 & $\mathrm{Mb}, \mathrm{Nb}$ & 5.7 & $\mathrm{HOL}$ & 1 & & 1 \\
\hline C. (Empeda) cinerascens & 15 & $\mathrm{Sb}, \mathrm{Mb}, \mathrm{Nb}$ & 24.7 & W PAL & & & \\
\hline C. (Empeda) neglecta & 10 & $\mathrm{Sb}, \mathrm{Mb}$ & 3.3 & W PAL & & & \\
\hline Chionea (Chionea) araneoides & 6 & $\mathrm{Sb}, \mathrm{Mb}, \mathrm{Nb}$ & 0.5 & W PAL & & & \\
\hline C. (C.) crassipes & 3 & $\mathrm{Mb}, \mathrm{Nb}$ & n.p. & Tr-PAL & 1 & & \\
\hline C. (Sphaeconophilus) lutescens & 6 & $\mathrm{Sb}, \mathrm{Mb}, \mathrm{Nb}$ & 0.2 & W PAL & & & \\
\hline Crypteria limnophiloides & 11 & $\mathrm{Sb}, \mathrm{Mb}, \mathrm{Nb}$ & 5.2 & W PAL & & & \\
\hline Dicranomyia (D.) aperta & 6 & $\mathrm{Sb}, \mathrm{Mb}, \mathrm{Nb}$ & 3.8 & $\mathrm{HOL}$ & & & 1 \\
\hline D. (D.) autumnalis & 13 & $\mathrm{Sb}, \mathrm{Mb}, \mathrm{Nb}$ & 4.3 & W PAL & & & \\
\hline D. (D.) consimilis & 11 & $\mathrm{Sb}, \mathrm{Mb}, \mathrm{Nb}$ & 3.6 & Tr-PAL & & & \\
\hline D. (D.) didyma & 11 & $\mathrm{Sb}, \mathrm{Mb}, \mathrm{Nb}$ & 3.3 & Tr-PAL & & & \\
\hline D. (D.) distendens & 18 & $\mathrm{Sb}, \mathrm{Mb}, \mathrm{Nb}$ & 41.6 & HOL & & & 1 \\
\hline D. (D.) frontalis & 17 & $\mathrm{Sb}, \mathrm{Mb}, \mathrm{Nb}$ & 4.8 & $\mathrm{HOL}$ & & & \\
\hline D. (D.) halterata & 9 & $\mathrm{Sb}, \mathrm{Mb}, \mathrm{Nb}$ & 1.7 & $\mathrm{HOL}$ & & & \\
\hline D. (D.) handlirschi & 5 & $\mathrm{Sb}, \mathrm{Mb}$ & 0.5 & Tr-PAL & & & \\
\hline D. (D.) hyalinata & 12 & $\mathrm{Sb}, \mathrm{Mb}, \mathrm{Nb}$ & 6.4 & $\mathrm{HOL}$ & 1 & & 1 \\
\hline D. (D.) longipennis & 3 & $\mathrm{Mb}, \mathrm{Nb}$ & 0.7 & $\mathrm{HOL}$ & & & 1 \\
\hline D. (D.) mitis & 12 & $\mathrm{Sb}, \mathrm{Mb}, \mathrm{Nb}$ & 1.2 & Tr-PAL & & & \\
\hline D. (D.) modesta & 20 & $\mathrm{Sb}, \mathrm{Mb}, \mathrm{Nb}$ & 26.1 & $\mathrm{HOL}$ & & & \\
\hline D. (D.) moniliformis & 2 & $\mathrm{Nb}$ & 0.5 & $\mathrm{HOL}$ & 1 & & 1 \\
\hline D. (D.) omissinervis & 3 & $\mathrm{Mb}, \mathrm{Nb}$ & 1.0 & Tr-PAL & & & \\
\hline D. (D.) patens & 13 & $\mathrm{Sb}, \mathrm{Mb}, \mathrm{Nb}$ & 2.4 & Tr-PAL & & & \\
\hline D. (D.) radegasti & 1 & $\mathrm{Sb}$ & 0.2 & W PAL & & & \\
\hline D. (D.) sera & 4 & $\mathrm{Sb}, \mathrm{Mb}$ & 1.2 & $\mathrm{HOL}$ & & & \\
\hline D. (D.) terraenovae & 17 & $\mathrm{Sb}, \mathrm{Mb}, \mathrm{Nb}$ & 18.8 & $\mathrm{HOL}$ & & & 1 \\
\hline D. (D.) ventralis & 11 & $\mathrm{Sb}, \mathrm{Mb}, \mathrm{Nb}$ & 5.5 & Tr-PAL & & & 1 \\
\hline D. (D.) zernyi & 4 & $\mathrm{Sb}, \mathrm{Mb}$ & 0.5 & Tr-PAL & & & \\
\hline D. (Glochina) liberta & 5 & $\mathrm{Sb}, \mathrm{Mb}$ & n.p. & $\mathrm{HOL}$ & 1 & & \\
\hline D. (G.) tristis & 6 & $\mathrm{Sb}, \mathrm{Nb}$ & 1.0 & Tr-PAL & & & \\
\hline D. (Idiopyga) danica & 3 & $\mathrm{Sb}$ & n.p. & Tr-PAL & & & \\
\hline D. (I.) esbeni & 1 & $\mathrm{Mb}$ & 0.2 & Tr-PAL & 1 & & \\
\hline D. (I.) halterella & 15 & $\mathrm{Sb}, \mathrm{Mb}, \mathrm{Nb}$ & 14.0 & $\mathrm{HOL}$ & & & \\
\hline D. (I.) intricata & 4 & $\mathrm{Mb}, \mathrm{Nb}$ & 1.7 & $\mathrm{HOL}$ & 1 & & 1 \\
\hline D. (I.) klefbecki & 1 & $\mathrm{Sb}$ & n.p. & $\mathrm{HOL}$ & 1 & & 1 \\
\hline D. (I.) lulensis & 3 & $\mathrm{Nb}$ & 2.9 & FENNSC & 1 & & 1 \\
\hline D. (I.) magnicauda & 11 & $\mathrm{Sb}, \mathrm{Mb}, \mathrm{Nb}$ & 0.5 & $\mathrm{HOL}$ & & & 1 \\
\hline D. (I.) murina & 3 & $\mathrm{Nb}$ & 0.5 & $\mathrm{HOL}$ & 1 & & \\
\hline D. (I.) ponojensis & 9 & $\mathrm{Sb}, \mathrm{Mb}, \mathrm{Nb}$ & 11.4 & $\mathrm{HOL}$ & 1 & & 1 \\
\hline
\end{tabular}


Table 6: Continued.

\begin{tabular}{|c|c|c|c|c|c|c|c|}
\hline & \multicolumn{5}{|c|}{ Range } & \multirow[b]{2}{*}{$S x^{6}$} & \multirow[b]{2}{*}{$\mathrm{Mi}^{7}$} \\
\hline & Prov. ${ }^{1}$ & $\mathrm{FIN}^{2}$ & $\mathrm{Mal}^{3}{ }^{3}$ & Glob $^{4}$ & No C EUR 5 & & \\
\hline D. (I.) stigmatica & 15 & $\mathrm{Sb}, \mathrm{Mb}, \mathrm{Nb}$ & 20.0 & Tr-PAL & & & 1 \\
\hline D. (Melanolimonia) caledonica & 3 & $\mathrm{Nb}$ & 2.9 & Tr-PAL & & & \\
\hline D. (M.) morio & 15 & $\mathrm{Sb}, \mathrm{Mb}, \mathrm{Nb}$ & 1.7 & Tr-PAL & & & \\
\hline D. (M.) occidua & 5 & $\mathrm{Mb}, \mathrm{Nb}$ & 2.9 & Tr-PAL & & & 1 \\
\hline D. (M.) rufiventris & 15 & $\mathrm{Sb}, \mathrm{Mb}, \mathrm{Nb}$ & 26.4 & Tr-PAL & & & 1 \\
\hline D. (M.) stylifera & 3 & $\mathrm{Nb}$ & 0.7 & W PAL & & & \\
\hline D. (Numantia) fusca & 8 & $\mathrm{Sb}, \mathrm{Mb}$ & 4.8 & $\mathrm{HOL}$ & & & \\
\hline Dicranoptycha cinerascens & 2 & $\mathrm{Sb}$ & n.p. & W PAL & & & \\
\hline D. fuscescens & 2 & $\mathrm{Sb}$ & n.p. & Tr-PAL & & & \\
\hline Dicranophragma (Brachylimnophila) separatum & 20 & $\mathrm{Sb}, \mathrm{Mb}, \mathrm{Nb}$ & 52.3 & W PAL & & & \\
\hline Discobola annulata & 16 & $\mathrm{Sb}, \mathrm{Mb}, \mathrm{Nb}$ & 12.8 & $\mathrm{HOL}$ & & 1 & \\
\hline D. caesarea & 14 & $\mathrm{Sb}, \mathrm{Mb}, \mathrm{Nb}$ & 5.9 & Tr-PAL & & 1 & \\
\hline Elephantomyia (E.) edwardsi & 3 & $\mathrm{Sb}$ & 0.5 & W PAL & & 1 & \\
\hline E. (E.) krivosheinae & 11 & $\mathrm{Sb}, \mathrm{Mb}, \mathrm{Nb}$ & 1.4 & Tr-PAL & & 1 & \\
\hline Eloeophila maculata & 15 & $\mathrm{Sb}, \mathrm{Mb}, \mathrm{Nb}$ & 16.2 & Tr-PAL & & & \\
\hline E. submarmorata & 4 & $\mathrm{Sb}, \mathrm{Mb}$ & 1.7 & W PAL & & & \\
\hline E. trimaculata & 18 & $\mathrm{Sb}, \mathrm{Mb}, \mathrm{Nb}$ & 19.2 & W PAL & & & \\
\hline E. verralli & 1 & $\mathrm{Sb}$ & n.p. & W PAL & & & \\
\hline Epiphragma (E.) ocellare & 12 & $\mathrm{Sb}, \mathrm{Mb}$ & 10.2 & $\mathrm{HOL}$ & & 1 & \\
\hline Erioconopa diuturna & 12 & $\mathrm{Sb}, \mathrm{Mb}, \mathrm{Nb}$ & 10.2 & W PAL & & & 1 \\
\hline E. trivialis & 13 & $\mathrm{Sb}, \mathrm{Mb}$ & 1.9 & W PAL & & & \\
\hline Erioptera (E.) beckeri & 13 & $\mathrm{Sb}, \mathrm{Mb}, \mathrm{Nb}$ & 2.6 & Tr-PAL & & & 1 \\
\hline E. (E.) divisa & 6 & $\mathrm{Sb}, \mathrm{Mb}$ & 2.1 & W PAL & & & \\
\hline E. (E.) flavata & 20 & $\mathrm{Sb}, \mathrm{Mb}, \mathrm{Nb}$ & 24.5 & Tr-PAL & & & 1 \\
\hline E. (E.) griseipennis & 2 & $\mathrm{Sb}$ & n.p. & W PAL & & & \\
\hline E. (E.) lutea & 19 & $\mathrm{Sb}, \mathrm{Mb}, \mathrm{Nb}$ & 32.3 & Tr-PAL & & & \\
\hline E. (E.) nielseni & 12 & $\mathrm{Sb}, \mathrm{Mb}, \mathrm{Nb}$ & 4.3 & W PAL & & & 1 \\
\hline E. (E.) pederi & 4 & $\mathrm{Sb}$ & 1.2 & Tr-PAL & & & \\
\hline E. (E.) sordida & 19 & $\mathrm{Sb}, \mathrm{Mb}, \mathrm{Nb}$ & 17.6 & Tr-PAL & & & \\
\hline E. (E.) squalida & 6 & $\mathrm{Sb}, \mathrm{Mb}, \mathrm{Nb}$ & 1.9 & W PAL & & & \\
\hline E. (E.) tordi & 1 & $\mathrm{Sb}$ & 0.2 & Tr-PAL & 1 & & \\
\hline Euphylidorea dispar & 5 & $\mathrm{Sb}$ & 1.7 & W PAL & & & \\
\hline E. meigenii & 14 & $\mathrm{Sb}, \mathrm{Mb}, \mathrm{Nb}$ & 12.4 & W PAL & & & 1 \\
\hline E. phaeostigma & 20 & $\mathrm{Sb}, \mathrm{Mb}, \mathrm{Nb}$ & 28.5 & W PAL & & & \\
\hline Eutonia barbipes & 4 & $\mathrm{Sb}$ & 0.2 & W PAL & & & \\
\hline Gnophomyia acheron & 2 & $\mathrm{Sb}, \mathrm{Mb}$ & 0.2 & Tr-PAL & 1 & 1 & \\
\hline G. lugubris & 5 & $\mathrm{Sb}, \mathrm{Mb}$ & 0.5 & Tr-PAL & & 1 & \\
\hline G. viridipennis & 3 & $\mathrm{Sb}$ & 0.2 & Tr-PAL & & 1 & \\
\hline Gonempeda flava & 1 & $\mathrm{Sb}$ & 0.2 & W PAL & & & \\
\hline Gonomyia (G.) abscondita & 6 & $\mathrm{Sb}, \mathrm{Mb}$ & 1.9 & W PAL & & & \\
\hline G. (G.) bifida & 2 & $\mathrm{Sb}$ & 0.2 & W PAL & & & \\
\hline G. (G.) dentata & 5 & $\mathrm{Sb}, \mathrm{Mb}$ & 0.5 & Tr-PAL & & & \\
\hline G. (G.) simplex & 7 & $\mathrm{Sb}, \mathrm{Mb}$ & 1.9 & W PAL & & & \\
\hline G. (G.) stackelbergi & 7 & $\mathrm{Mb}, \mathrm{Nb}$ & 8.6 & Tr-PAL & 1 & & \\
\hline G. (G.) tenella & 3 & $\mathrm{Sb}$ & 0.2 & W PAL & & & \\
\hline G. (Teuchogonomyia) edwardsi & 2 & $\mathrm{Sb}$ & n.p. & Tr-PAL & & & \\
\hline Helius (H.) flavus & 6 & $\mathrm{Sb}$ & 1.2 & Tr-PAL & & & \\
\hline H. (H.) longirostris & 17 & $\mathrm{Sb}, \mathrm{Mb}, \mathrm{Nb}$ & 7.4 & W PAL & & & \\
\hline H. (H.) pallirostris & 1 & $\mathrm{Sb}$ & n.p. & Tr-PAL & & & \\
\hline Hexatoma (H.) fuscipennis & 7 & $\mathrm{Mb}, \mathrm{Nb}$ & 0.2 & W PAL & & & \\
\hline
\end{tabular}


Table 6: Continued.

\begin{tabular}{|c|c|c|c|c|c|c|c|}
\hline & \multicolumn{5}{|c|}{ Range } & \multirow[b]{2}{*}{$\mathrm{Sx}^{6}$} & \multirow[b]{2}{*}{$\mathrm{Mi}^{\top}$} \\
\hline & Prov. ${ }^{1}$ & $\mathrm{FIN}^{2}$ & $\mathrm{Mal}^{3}{ }^{3}$ & Glob $^{4}$ & No C EUR 5 & & \\
\hline Hoplolabis (Parilisia) areolata & 4 & $\mathrm{Sb}, \mathrm{Nb}$ & 0.2 & W PAL & & & \\
\hline H. (P.) vicina & 9 & $\mathrm{Sb}, \mathrm{Mb}, \mathrm{Nb}$ & 1.0 & Tr-PAL & & & \\
\hline Idioptera linnei & 15 & $\mathrm{Sb}, \mathrm{Mb}, \mathrm{Nb}$ & 12.8 & Tr-PAL & & & 1 \\
\hline I. pulchella & 19 & $\mathrm{Sb}, \mathrm{Mb}, \mathrm{Nb}$ & 23.5 & Tr-PAL & & & \\
\hline Libnotes (Afrolimonia) ladogensis & 3 & $\mathrm{Sb}, \mathrm{Mb}$ & 0.5 & Tr-PAL & & 1 & \\
\hline Limnophila (L.) pictipennis & 1 & $\mathrm{Sb}$ & n.p. & Tr-PAL & & & \\
\hline L. (L.) schranki & 16 & $\mathrm{Sb}, \mathrm{Mb}, \mathrm{Nb}$ & 8.3 & Tr-PAL & & & \\
\hline Limonia badia & 6 & $\mathrm{Sb}, \mathrm{Mb}$ & n.p. & $\mathrm{HOL}$ & 1 & 1 & \\
\hline L. flavipes & 13 & $\mathrm{Sb}, \mathrm{Mb}, \mathrm{Nb}$ & 12.1 & W PAL & & & \\
\hline L. macrostigma & 18 & $\mathrm{Sb}, \mathrm{Mb}, \mathrm{Nb}$ & 11.9 & Tr-PAL & & & \\
\hline L. maculicosta & 1 & $\mathrm{Nb}$ & n.p. & $\mathrm{HOL}$ & 1 & & \\
\hline L. messaurea & 1 & $\mathrm{Mb}$ & n.p. & FENNSC & 1 & & \\
\hline L. nubeculosa & 8 & $\mathrm{Sb}, \mathrm{Mb}$ & 1.0 & HOL & & & \\
\hline L. phragmitidis & 15 & $\mathrm{Sb}, \mathrm{Mb}, \mathrm{Nb}$ & 6.2 & Tr-PAL & & & \\
\hline L. stigma & 4 & $\mathrm{Sb}, \mathrm{Mb}$ & 0.2 & W PAL & & & \\
\hline L. sylvicola & 16 & $\mathrm{Sb}, \mathrm{Mb}, \mathrm{Nb}$ & 10.5 & Tr-PAL & & & \\
\hline L. trivittata & 17 & $\mathrm{Sb}, \mathrm{Mb}, \mathrm{Nb}$ & 5.0 & Tr-PAL & & & \\
\hline Lipsothrix ecucullata & 11 & $\mathrm{Sb}, \mathrm{Mb}, \mathrm{Nb}$ & 9.5 & W PAL & & 1 & \\
\hline L. errans & 1 & $\mathrm{Sb}$ & 0.5 & W PAL & & 1 & \\
\hline Metalimnobia (M.) bifasciata & 19 & $\mathrm{Sb}, \mathrm{Mb}, \mathrm{Nb}$ & 22.1 & Tr-PAL & & 1 & \\
\hline M. (M.) charlesi & 11 & $\mathrm{Sb}, \mathrm{Mb}, \mathrm{Nb}$ & 4.3 & W PAL & & 1 & \\
\hline M. (M.) quadrimaculata & 20 & $\mathrm{Sb}, \mathrm{Mb}, \mathrm{Nb}$ & 11.9 & $\mathrm{HOL}$ & & 1 & \\
\hline M. (M.) quadrinotata & 20 & $\mathrm{Sb}, \mathrm{Mb}, \mathrm{Nb}$ & 33.5 & Tr-PAL & & 1 & \\
\hline M. (M.) tenua & 12 & $\mathrm{Sb}, \mathrm{Mb}, \mathrm{Nb}$ & 11.4 & Tr-PAL & & 1 & \\
\hline M. (M.) zetterstedti & 20 & $\mathrm{Sb}, \mathrm{Mb}, \mathrm{Nb}$ & 50.1 & Tr-PAL & & 1 & \\
\hline Molophilus (M.) appendiculatus & 12 & $\mathrm{Sb}, \mathrm{Mb}, \mathrm{Nb}$ & 8.3 & Tr-PAL & & & \\
\hline M. (M.) ater & 18 & $\mathrm{Sb}, \mathrm{Mb}, \mathrm{Nb}$ & 12.8 & Tr-PAL & & & \\
\hline M. (M.) bifidus & 4 & $\mathrm{Sb}, \mathrm{Nb}$ & 0.7 & W PAL & & & \\
\hline M. (M.) bihamatus & 10 & $\mathrm{Sb}, \mathrm{Mb}, \mathrm{Nb}$ & 7.1 & W PAL & & & 1 \\
\hline M. (M.) cinereifrons & 7 & $\mathrm{Sb}, \mathrm{Mb}$ & 2.6 & W PAL & & & \\
\hline M. (M.) corniger & 7 & $\mathrm{Sb}, \mathrm{Mb}$ & 6.9 & W PAL & & & \\
\hline M. (M.) crassipygus & 18 & $\mathrm{Sb}, \mathrm{Mb}, \mathrm{Nb}$ & 17.3 & W PAL & & & \\
\hline M. (M.) flavus & 19 & $\mathrm{Sb}, \mathrm{Mb}, \mathrm{Nb}$ & 50.4 & W PAL & & & \\
\hline M. (M.) griseus & 11 & $\mathrm{Sb}, \mathrm{Mb}, \mathrm{Nb}$ & 4.0 & W PAL & & & \\
\hline M. (M.) medius & 8 & $\mathrm{Sb}, \mathrm{Mb}$ & 6.7 & W PAL & & & \\
\hline M. (M.) obscurus & 1 & $\mathrm{Sb}$ & n.p. & W PAL & & & \\
\hline M. (M.) occultus & 1 & $\mathrm{Sb}$ & 0.2 & W PAL & & & 1 \\
\hline M. (M.) ochraceus & 11 & $\mathrm{Sb}, \mathrm{Mb}$ & 5.9 & W PAL & & & \\
\hline M. (M.) propinquus & 16 & $\mathrm{Sb}, \mathrm{Mb}, \mathrm{Nb}$ & 9.0 & Tr-PAL & & & \\
\hline M. (M.) pullus & 2 & $\mathrm{Sb}$ & 0.7 & W PAL & & & \\
\hline Neolimnomyia (N.) batava & 3 & $\mathrm{Sb}$ & 1.0 & W PAL & & & \\
\hline Neolimnophila carteri & 8 & $\mathrm{Sb}, \mathrm{Mb}$ & 6.4 & W PAL & & & \\
\hline N. placida & 8 & $\mathrm{Sb}, \mathrm{Mb}$ & 0.2 & Tr-PAL & & & \\
\hline Neolimonia dumetorum & 11 & $\mathrm{Sb}, \mathrm{Mb}$ & 8.1 & W PAL & & 1 & \\
\hline Orimarga (O.) attenuata & 8 & $\mathrm{Sb}, \mathrm{Mb}, \mathrm{Nb}$ & 8.6 & Tr-PAL & & & 1 \\
\hline O. (O.) juvenilis & 2 & $\mathrm{Mb}, \mathrm{Nb}$ & 0.2 & W PAL & & & 1 \\
\hline Ormosia (Oreophila) sootryeni & 8 & $\mathrm{Sb}, \mathrm{Mb}, \mathrm{Nb}$ & 2.4 & Tr-PAL & 1 & & \\
\hline O. (Ormosia) brevinervis & 1 & $\mathrm{Nb}$ & n.p. & W PAL & 1 & & \\
\hline O. (O.) clavata & 6 & $\mathrm{Sb}, \mathrm{Mb}$ & 5.9 & W PAL & & & \\
\hline O. (O.) depilata & 15 & $\mathrm{Sb}, \mathrm{Mb}, \mathrm{Nb}$ & 33.7 & W PAL & & & \\
\hline
\end{tabular}


Table 6: Continued.

\begin{tabular}{|c|c|c|c|c|c|c|c|}
\hline & \multicolumn{5}{|c|}{ Range } & \multirow[b]{2}{*}{$S x^{6}$} & \multirow[b]{2}{*}{$\mathrm{Mi}^{7}$} \\
\hline & Prov. $^{1}$ & $\mathrm{FIN}^{2}$ & $\mathrm{Mal}^{3}{ }^{3}$ & Glob $^{4}$ & No C EUR ${ }^{5}$ & & \\
\hline O. (O.) fascipennis & 6 & $\mathrm{Sb}, \mathrm{Nb}$ & 0.7 & $\mathrm{HOL}$ & & & \\
\hline O. (O.) hederae & 1 & $\mathrm{Sb}$ & n.p. & Tr-PAL & & & \\
\hline O. (O.) lineata & 12 & $\mathrm{Sb}, \mathrm{Mb}$ & 10.0 & W PAL & & & \\
\hline O. (O.) loxia & 4 & $\mathrm{Sb}$ & 1.2 & W PAL & & & \\
\hline O. (O.) pseudosimilis & 16 & $\mathrm{Sb}, \mathrm{Mb}, \mathrm{Nb}$ & 13.3 & W PAL & & & \\
\hline O. (O.) ruficauda & 20 & $\mathrm{Sb}, \mathrm{Mb}, \mathrm{Nb}$ & 67.7 & W PAL & & & \\
\hline O. (O.) staegeriana & 18 & $\mathrm{Sb}, \mathrm{Mb}, \mathrm{Nb}$ & 11.6 & W PAL & & & \\
\hline Paradelphomyia (Oxyrhiza) fuscula & 9 & $\mathrm{Sb}, \mathrm{Mb}$ & 14.7 & W PAL & & & \\
\hline P. (O.) nigrina & 3 & $\mathrm{Sb}, \mathrm{Nb}$ & 1.9 & W PAL & & & 1 \\
\hline P. (Macrolabina) nigronotata & 2 & $\mathrm{Sb}, \mathrm{Nb}$ & n.p. & Tr-PAL & & & \\
\hline P. (Paraphylidorea) fulvonervosa & 19 & $\mathrm{Sb}, \mathrm{Mb}, \mathrm{Nb}$ & 41.1 & Tr-PAL & & & \\
\hline Phylidorea (P.) abdominalis & 16 & $\mathrm{Sb}, \mathrm{Mb}, \mathrm{Nb}$ & 7.4 & W PAL & & & 1 \\
\hline P. (P.) bicolor & 14 & $\mathrm{Sb}, \mathrm{Mb}, \mathrm{Nb}$ & 3.6 & W PAL & & & \\
\hline P. (P.) ferruginea & 14 & $\mathrm{Sb}, \mathrm{Mb}, \mathrm{Nb}$ & 10.2 & Tr-PAL & & & \\
\hline P. (P.) heterogyna & 16 & $\mathrm{Sb}, \mathrm{Mb}, \mathrm{Nb}$ & 11.4 & W PAL & & & 1 \\
\hline P. (P.) longicornis & 18 & $\mathrm{Sb}, \mathrm{Mb}, \mathrm{Nb}$ & 11.9 & Tr-PAL & & & \\
\hline P. (P.) nervosa & 7 & $\mathrm{Sb}, \mathrm{Mb}$ & 1.7 & W PAL & & & \\
\hline P. (P.) squalens & 19 & $\mathrm{Sb}, \mathrm{Mb}, \mathrm{Nb}$ & 37.8 & Tr-PAL & & & 1 \\
\hline P. (P.) umbrarum & 4 & $\mathrm{Nb}$ & 5.9 & Tr-PAL & 1 & & 1 \\
\hline Phyllolabis macroura & 4 & $\mathrm{Sb}, \mathrm{Nb}$ & 1.7 & W PAL & & & \\
\hline Pilaria decolor & 19 & $\mathrm{Sb}, \mathrm{Mb}, \mathrm{Nb}$ & 8.6 & W PAL & & & \\
\hline P. discicollis & 13 & $\mathrm{Sb}, \mathrm{Mb}, \mathrm{Nb}$ & 2.6 & W PAL & & & \\
\hline P. meridiana & 18 & $\mathrm{Sb}, \mathrm{Mb}, \mathrm{Nb}$ & 12.4 & $\mathrm{HOL}$ & & & \\
\hline P. nigropunctata & 4 & $\mathrm{Sb}, \mathrm{Mb}$ & 0.5 & W PAL & & & \\
\hline P. scutellata & 3 & $\mathrm{Sb}$ & 0.2 & Tr-PAL & & & \\
\hline Pseudolimnophila (P.) lucorum & 4 & $\mathrm{Sb}, \mathrm{Mb}$ & 1.2 & Tr-PAL & & & \\
\hline Rhabdomastix (R.) borealis & 1 & $\mathrm{Nb}$ & n.p. & $\mathrm{HOL}$ & 1 & & \\
\hline R. (R.) laeta & 8 & $\mathrm{Sb}, \mathrm{Mb}, \mathrm{Nb}$ & 3.1 & Tr-PAL & & & \\
\hline R. (unplaced) parva & 1 & $\mathrm{Nb}$ & 0.5 & FENNSC & 1 & & \\
\hline Rhipidia (R.) maculata & 20 & $\mathrm{Sb}, \mathrm{Mb}, \mathrm{Nb}$ & 25.7 & $\mathrm{HOL}$ & & & \\
\hline R. (R.) uniseriata & 16 & $\mathrm{Sb}, \mathrm{Mb}, \mathrm{Nb}$ & 3.3 & Tr-PAL & & 1 & \\
\hline Rhypholophus haemorrhoidalis & 16 & $\mathrm{Sb}, \mathrm{Mb}, \mathrm{Nb}$ & 13.1 & W PAL & & & \\
\hline R. varius & 5 & $\mathrm{Sb}$ & 1.9 & W PAL & & & \\
\hline Scleroprocta pentagonalis & 2 & $\mathrm{Mb}$ & 1.0 & Tr-PAL & & & \\
\hline S. sororcula & 16 & $\mathrm{Sb}, \mathrm{Mb}, \mathrm{Nb}$ & 16.6 & W PAL & & & \\
\hline Symplecta (Psiloconopa) lindrothi & 7 & $\mathrm{Sb}, \mathrm{Mb}, \mathrm{Nb}$ & 1.0 & FENNSC & 1 & & \\
\hline S. (P.) meigeni & 7 & $\mathrm{Mb}, \mathrm{Nb}$ & 3.1 & Tr-PAL & & & \\
\hline S. (P.) stictica & 8 & $\mathrm{Sb}, \mathrm{Mb}$ & 1.7 & Tr-PAL & & & \\
\hline S. (S.) chosenensis & 1 & $\mathrm{Sb}$ & n.p. & Tr-PAL & & & \\
\hline S. (S.) hybrida & 16 & $\mathrm{Sb}, \mathrm{Mb}, \mathrm{Nb}$ & 4.5 & $\mathrm{HOL}$ & & & \\
\hline S. (S.) scotica & 5 & $\mathrm{Sb}, \mathrm{Mb}, \mathrm{Nb}$ & 0.5 & $\mathrm{HOL}$ & & & \\
\hline S. (S.) mabelana & 2 & $\mathrm{Nb}$ & 0.2 & $\mathrm{HOL}$ & & & \\
\hline S. (Trimicra) pilipes & 2 & $\mathrm{Sb}$ & n.p. & $\mathrm{HOL}$ & & & \\
\hline Tasiocera (Dasymolophilus) exigua & 10 & $\mathrm{Sb}, \mathrm{Mb}, \mathrm{Nb}$ & 10.5 & W PAL & & & \\
\hline T. (D.) fuscescens & 2 & $\mathrm{Sb}$ & 1.2 & W PAL & & & \\
\hline T. (D.) murina & 4 & $\mathrm{Sb}, \mathrm{Nb}$ & 1.7 & W PAL & & & \\
\hline \multicolumn{8}{|l|}{ Tipulidae } \\
\hline Angarotipula tumidicornis & 7 & $\mathrm{Sb}, \mathrm{Mb}, \mathrm{Nb}$ & 6.2 & Tr-PAL & 1 & & 1 \\
\hline Ctenophora (C.) flaveolata & 2 & $\mathrm{Sb}$ & n.p. & W PAL & & 1 & \\
\hline C. (C.) guttata & 11 & $\mathrm{Sb}, \mathrm{Mb}$ & 0.2 & Tr-PAL & & 1 & \\
\hline
\end{tabular}


Table 6: Continued.

\begin{tabular}{|c|c|c|c|c|c|c|c|}
\hline & \multicolumn{5}{|c|}{ Range } & \multirow[b]{2}{*}{$S x^{6}$} & \multirow[b]{2}{*}{$\mathrm{Mi}^{7}$} \\
\hline & Prov. ${ }^{1}$ & $\mathrm{FIN}^{2}$ & $\mathrm{Mal}^{3}{ }^{3}$ & Glob $^{4}$ & No C EUR 5 & & \\
\hline C. (C.) nigriceps & 1 & $\mathrm{Mb}$ & 0.2 & W PAL & & 1 & \\
\hline C. (C.) pectinicornis & 2 & $\mathrm{Sb}$ & n.p. & W PAL & & 1 & \\
\hline Dictenidia bimaculata & 18 & $\mathrm{Sb}, \mathrm{Mb}, \mathrm{Nb}$ & 12.4 & Tr-PAL & & 1 & \\
\hline Dolichopeza (D.) albipes & 9 & $\mathrm{Sb}, \mathrm{Mb}, \mathrm{Nb}$ & 2.9 & W PAL & & & \\
\hline D. (D.) bifida & 4 & $\mathrm{Sb}, \mathrm{Mb}, \mathrm{Nb}$ & 1.0 & Tr-PAL & & & \\
\hline Nephrotoma aculeata & 12 & $\mathrm{Sb}, \mathrm{Mb}$ & 1.7 & Tr-PAL & & & \\
\hline N. analis & 10 & $\mathrm{Sb}, \mathrm{Mb}$ & 4.0 & Tr-PAL & & & \\
\hline N. appendiculata & 9 & $\mathrm{Sb}, \mathrm{Mb}$ & 0.7 & W PAL & & & \\
\hline N. cornicina & 14 & $\mathrm{Sb}, \mathrm{Mb}$ & 1.2 & $\mathrm{HOL}$ & & & \\
\hline N. crocata & 11 & $\mathrm{Sb}, \mathrm{Mb}$ & n.p. & Tr-PAL & & & \\
\hline N. dorsalis & 10 & $\mathrm{Sb}, \mathrm{Mb}, \mathrm{Nb}$ & 1.7 & Tr-PAL & & & \\
\hline N. flavescens & 11 & $\mathrm{Sb}, \mathrm{Mb}$ & 1.4 & HOL & & & \\
\hline N. lundbecki & 1 & $\mathrm{Nb}$ & n.p. & $\mathrm{HOL}$ & 1 & & \\
\hline N. lunulicornis & 11 & $\mathrm{Sb}, \mathrm{Mb}$ & 3.1 & Tr-PAL & & & \\
\hline N. pratensis & 5 & $\mathrm{Sb}$ & n.p. & Tr-PAL & & & \\
\hline N. quadristriata & 7 & $\mathrm{Sb}, \mathrm{Nb}$ & n.p. & Tr-PAL & & & \\
\hline N. relicta & 1 & $\mathrm{Nb}$ & n.p. & Tr-PAL & 1 & & \\
\hline N. scurra & 19 & $\mathrm{Sb}, \mathrm{Mb}, \mathrm{Nb}$ & 1.4 & Tr-PAL & & & \\
\hline N. submaculosa & 1 & $\mathrm{Mb}$ & n.p. & W PAL & & & \\
\hline N. tenuipes & 12 & $\mathrm{Sb}, \mathrm{Mb}, \mathrm{Nb}$ & 1.4 & Tr-PAL & & & \\
\hline Nigrotipula nigra & 14 & $\mathrm{Sb}, \mathrm{Mb}, \mathrm{Nb}$ & 1.4 & Tr-PAL & & & \\
\hline Phoroctenia vittata & 6 & $\mathrm{Sb}, \mathrm{Mb}, \mathrm{Nb}$ & 1.0 & Tr-PAL & & 1 & \\
\hline Prionocera abscondita & 2 & $\mathrm{Nb}$ & 1.0 & Tr-PAL & 1 & & 1 \\
\hline P. chosenicola & 11 & $\mathrm{Sb}, \mathrm{Mb}, \mathrm{Nb}$ & 3.3 & $\mathrm{HOL}$ & & & 1 \\
\hline P. pubescens & 16 & $\mathrm{Sb}, \mathrm{Mb}, \mathrm{Nb}$ & 14.0 & $\mathrm{HOL}$ & & & 1 \\
\hline P. recta & 4 & $\mathrm{Nb}$ & 1.2 & $\mathrm{HOL}$ & 1 & & 1 \\
\hline P. ringdahli & 6 & $\mathrm{Mb}, \mathrm{Nb}$ & 3.6 & $\mathrm{HOL}$ & 1 & & 1 \\
\hline P. serricornis & 7 & $\mathrm{Sb}, \mathrm{Nb}$ & 5.5 & Tr-PAL & 1 & & 1 \\
\hline P. subserricornis & 19 & $\mathrm{Sb}, \mathrm{Mb}, \mathrm{Nb}$ & 13.5 & $\mathrm{HOL}$ & & & 1 \\
\hline P. turcica & 18 & $\mathrm{Sb}, \mathrm{Mb}, \mathrm{Nb}$ & 13.5 & HOL & & & 1 \\
\hline P. woodorum & 4 & $\mathrm{Mb}, \mathrm{Nb}$ & 1.4 & $\mathrm{HOL}$ & 1 & & 1 \\
\hline Tanyptera (T.) atrata & 19 & $\mathrm{Sb}, \mathrm{Mb}, \mathrm{Nb}$ & 10.9 & Tr-PAL & & 1 & \\
\hline T. (T.) nigricornis & 14 & $\mathrm{Sb}, \mathrm{Mb}, \mathrm{Nb}$ & 3.3 & Tr-PAL & & 1 & \\
\hline Tipula (Acutipula) fulvipennis & 13 & $\mathrm{Sb}, \mathrm{Mb}, \mathrm{Nb}$ & 6.4 & Tr-PAL & & & \\
\hline T. (A.) maxima & 5 & $\mathrm{Sb}$ & 1.7 & W PAL & & & \\
\hline T. (Arctotipula) salicetorum & 4 & $\mathrm{Nb}$ & 0.5 & Tr-PAL & 1 & & \\
\hline T. (Beringotipula) unca & 17 & $\mathrm{Sb}, \mathrm{Mb}, \mathrm{Nb}$ & 4.0 & Tr-PAL & & & \\
\hline T. (Dendrotipula) flavolineata & 5 & $\mathrm{Sb}$ & 1.2 & Tr-PAL & & 1 & \\
\hline T. (Emodotipula) obscuriventris & 3 & $\mathrm{Mb}, \mathrm{Nb}$ & 1.0 & W PAL & & & \\
\hline T. (Lindnerina) bistilata & 9 & $\mathrm{Sb}, \mathrm{Mb}, \mathrm{Nb}$ & 0.2 & Tr-PAL & & & \\
\hline T. (L.) subexcisa & 5 & $\mathrm{Nb}$ & 0.5 & Tr-PAL & 1 & & \\
\hline T. (Lunatipula) affinis & 12 & $\mathrm{Sb}, \mathrm{Mb}, \mathrm{Nb}$ & 0.5 & Tr-PAL & & & \\
\hline T. (L.) circumdata & 14 & $\mathrm{Sb}, \mathrm{Mb}, \mathrm{Nb}$ & 1.7 & Tr-PAL & & & \\
\hline T. (L.) fascipennis & 13 & $\mathrm{Sb}, \mathrm{Mb}$ & 4.5 & W PAL & & & \\
\hline T. (L.) humilis & 9 & $\mathrm{Sb}, \mathrm{Mb}, \mathrm{Nb}$ & 0.7 & Tr-PAL & & & \\
\hline T. (L.) laetabilis & 12 & $\mathrm{Sb}, \mathrm{Mb}, \mathrm{Nb}$ & 1.9 & Tr-PAL & & & \\
\hline T. (L.) limitata & 16 & $\mathrm{Sb}, \mathrm{Mb}, \mathrm{Nb}$ & 11.2 & Tr-PAL & & & \\
\hline T. (L.) lunata & 15 & $\mathrm{Sb}, \mathrm{Mb}, \mathrm{Nb}$ & 3.1 & Tr-PAL & & & \\
\hline T. (L.) recticornis & 2 & $\mathrm{Sb}$ & 0.2 & Tr-PAL & & & \\
\hline T. (L.) selene & 9 & $\mathrm{Sb}, \mathrm{Mb}$ & n.p. & W PAL & & 1 & \\
\hline
\end{tabular}


Table 6: Continued.

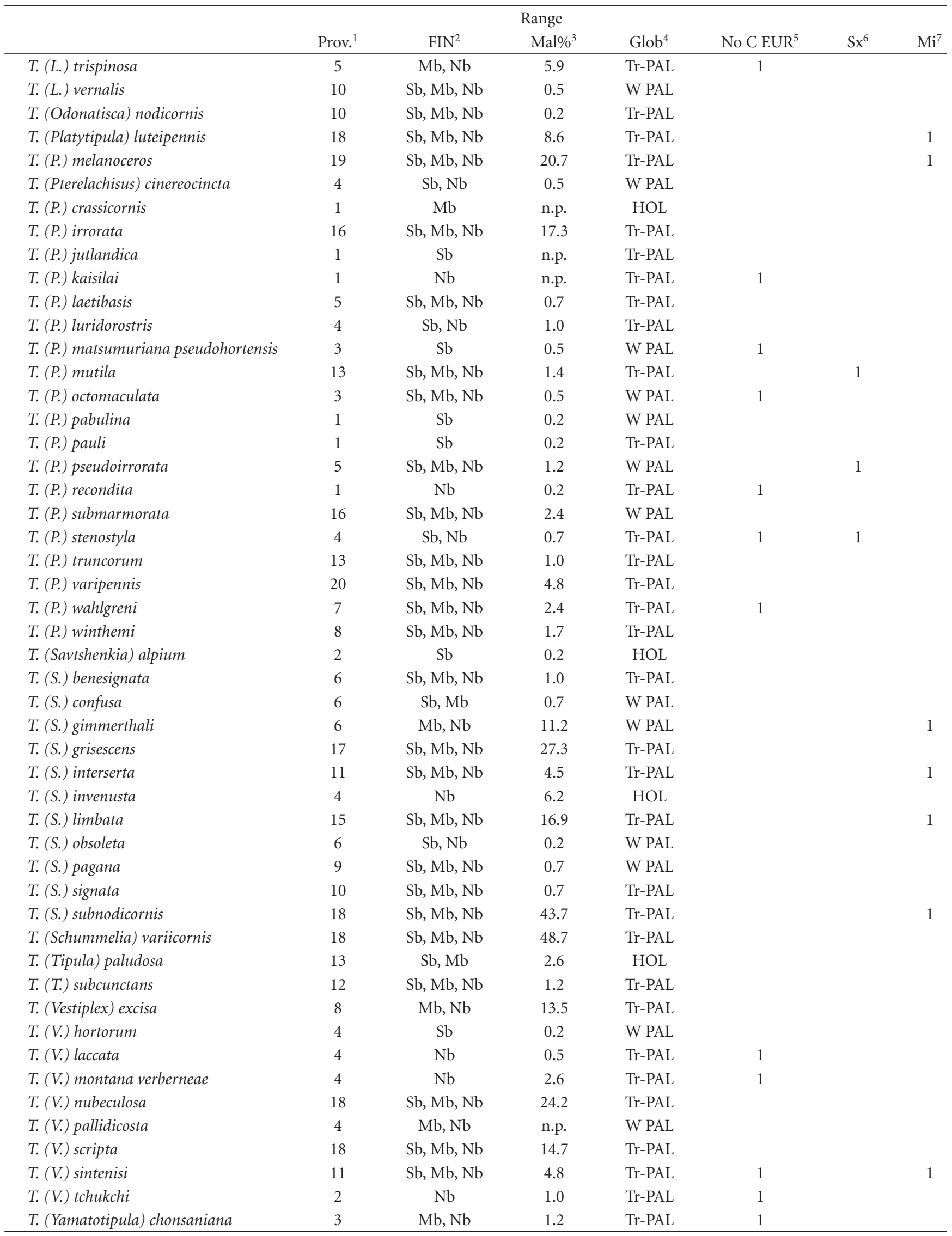


TABle 6: Continued.

\begin{tabular}{|c|c|c|c|c|c|c|c|}
\hline & & & Range & & & & \\
\hline & Prov. ${ }^{1}$ & $\mathrm{FIN}^{2}$ & $\mathrm{Mal} \%^{3}$ & Glob $^{4}$ & No C EUR ${ }^{5}$ & $S x^{6}$ & $\mathrm{Mi}^{7}$ \\
\hline T. (Y.) coerulescens & 13 & $\mathrm{Sb}, \mathrm{Mb}, \mathrm{Nb}$ & 3.6 & W PAL & & & \\
\hline T. (Y.) couckei & 10 & $\mathrm{Sb}, \mathrm{Mb}, \mathrm{Nb}$ & 1.0 & Tr-PAL & & & \\
\hline T. (Y.) fendleri & 4 & $\mathrm{Nb}$ & 1.9 & FENNSC & 1 & & \\
\hline T. (Y.) freyana & 4 & $\mathrm{Mb}, \mathrm{Nb}$ & 1.9 & Tr-PAL & 1 & & \\
\hline T. (Y.) lateralis & 14 & $\mathrm{Sb}, \mathrm{Mb}, \mathrm{Nb}$ & 2.6 & Tr-PAL & & & \\
\hline T. (Y.) marginella & 7 & $\mathrm{Sb}, \mathrm{Mb}$ & 0.2 & Tr-PAL & & & \\
\hline T. (Y.) moesta & 3 & $\mathrm{Nb}$ & 4.8 & Tr-PAL & 1 & & \\
\hline T. (Y.) montium & 9 & $\mathrm{Sb}, \mathrm{Mb}, \mathrm{Nb}$ & 1.2 & Tr-PAL & & & \\
\hline T. (Y.) pierrei & 13 & $\mathrm{Sb}, \mathrm{Mb}, \mathrm{Nb}$ & 0.5 & Tr-PAL & & & \\
\hline T. (Y.) pruinosa & 15 & $\mathrm{Sb}, \mathrm{Mb}, \mathrm{Nb}$ & 4.5 & Tr-PAL & & & \\
\hline T. (Y.) quadrivittata & 9 & $\mathrm{Sb}, \mathrm{Mb}, \mathrm{Nb}$ & 1.4 & W PAL & & & \\
\hline Pediciidae & & & & & & & \\
\hline Dicranota (D.) bimaculata & 15 & $\mathrm{Sb}, \mathrm{Mb}, \mathrm{Nb}$ & 18.3 & Tr-PAL & & & \\
\hline D. (D.) crassicauda & 1 & $\mathrm{Nb}$ & n.p. & Tr-PAL & 1 & & \\
\hline D. (D.) guerini & 17 & $\mathrm{Sb}, \mathrm{Mb}, \mathrm{Nb}$ & 22.3 & Tr-PAL & & & \\
\hline D. (Paradicranota) gracilipes & 11 & $\mathrm{Sb}, \mathrm{Mb}, \mathrm{Nb}$ & 5.0 & W PAL & & & \\
\hline D. (P.) pavida & 16 & $\mathrm{Sb}, \mathrm{Mb}, \mathrm{Nb}$ & 8.6 & W PAL & & & \\
\hline D. (P.) robusta & 4 & $\mathrm{Nb}$ & 1.2 & W PAL & & & \\
\hline D. (P.) subtilis & 3 & $\mathrm{Nb}$ & 0.5 & W PAL & & & \\
\hline D. (Rhaphidolabis) exclusa & 17 & $\mathrm{Sb}, \mathrm{Mb}, \mathrm{Nb}$ & 16.6 & Tr-PAL & & & \\
\hline Pedicia (Crunobia) straminea & 13 & $\mathrm{Sb}, \mathrm{Mb}, \mathrm{Nb}$ & 24.0 & W PAL & & & \\
\hline P. (P.) rivosa & 20 & $\mathrm{Sb}, \mathrm{Mb}, \mathrm{Nb}$ & 55.8 & Tr-PAL & & & \\
\hline Tricyphona (T.) immaculata & 19 & $\mathrm{Sb}, \mathrm{Mb}, \mathrm{Nb}$ & 77.2 & Tr-PAL & & & \\
\hline T. (T.) livida & 13 & $\mathrm{Sb}, \mathrm{Mb}, \mathrm{Nb}$ & 18.5 & W PAL & & & \\
\hline T. (T.) schummeli & 17 & $\mathrm{Sb}, \mathrm{Mb}, \mathrm{Nb}$ & 13.1 & W PAL & & & \\
\hline T. (T.) unicolor & 17 & $\mathrm{Sb}, \mathrm{Mb}, \mathrm{Nb}$ & 26.6 & W PAL & & & 1 \\
\hline Ula (U.) bolitophila & 11 & $\mathrm{Sb}, \mathrm{Mb}, \mathrm{Nb}$ & 4.3 & Tr-PAL & & 1 & \\
\hline U. (U.) kiushiuensis & 9 & $\mathrm{Sb}, \mathrm{Mb}, \mathrm{Nb}$ & 2.9 & Tr-PAL & 1 & 1 & \\
\hline U. (U.) mixta & 16 & $\mathrm{Sb}, \mathrm{Mb}, \mathrm{Nb}$ & 28.7 & W PAL & & 1 & \\
\hline U. (U.) mollissima & 7 & $\mathrm{Sb}, \mathrm{Mb}, \mathrm{Nb}$ & 2.4 & W PAL & & 1 & \\
\hline U. (U.) sylvatica & 19 & $\mathrm{Sb}, \mathrm{Mb}, \mathrm{Nb}$ & 35.9 & $\mathrm{HOL}$ & & 1 & \\
\hline Cylindrotomidae & & & & & & & \\
\hline Cylindrotoma borealis & 7 & $\mathrm{Sb}, \mathrm{Mb}, \mathrm{Nb}$ & 0.7 & FENNSC & 1 & & \\
\hline C. distinctissima & 17 & $\mathrm{Sb}, \mathrm{Mb}, \mathrm{Nb}$ & 16.2 & $\mathrm{HOL}$ & & & \\
\hline C. nigriventris & 6 & $\mathrm{Sb}, \mathrm{Mb}$ & 0.7 & Tr-PAL & 1 & & \\
\hline Diogma caudata & 10 & $\mathrm{Sb}, \mathrm{Mb}, \mathrm{Nb}$ & 7.6 & Tr-PAL & 1 & & \\
\hline D. glabrata & 13 & $\mathrm{Sb}, \mathrm{Mb}, \mathrm{Nb}$ & 14.3 & Tr-PAL & & & \\
\hline Phalacrocera replicata & 19 & $\mathrm{Sb}, \mathrm{Mb}, \mathrm{Nb}$ & 16.9 & HOL & & & 1 \\
\hline Triogma trisulcata & 8 & $\mathrm{Sb}, \mathrm{Mb}, \mathrm{Nb}$ & 2.9 & Tr-PAL & & & 1 \\
\hline
\end{tabular}

${ }^{1}$ Number of occupied provinces in Finland. ${ }^{2}$ Range in Finland, Sb: hemi- and south boreal, Mb: middle boreal, and Nb: north boreal zone. ${ }^{3}$ Occupancy frequency in Finnish Malaise trapping data (out of 421 sites; some closely laying sites were combined to the sites $\times$ species matrix, that is why a smaller figure than 476 is given in the text), n.p.: not present. ${ }^{4}$ Global range, HOL: Holarctic, Tr-PAL: Trans-Palaearctic, W PAL: West Palaearctic, and FENNSC: Fennoscandian. ${ }^{5}$ Species not occurring in Central Europe. ${ }^{6}$ Saproxylix and fungivorous species. ${ }^{7}$ Mire-dwelling species.

(J. Salmela, pers. obs.). It is likely that the species occurs east of Fennoscandia, even though so far it has not been recorded there. Limonia messaurea messaurea is known from Sweden and Finland [56], apparently only from two localities. The species has a subspecies $L . m$. boreoorientalis that is known from Kamchatka, Russia [98]; this eastern Palaearctic subspecies differs from the nominotypical form only in color pattern, not by male genitalia [98]. Both subspecies are perhaps associated with pine bogs $[98,99]$. Given the ambiguous nature of subspecies in crane fly taxonomy [100], it is likely that L. messaurea is a wide-ranging but disjunct Palaearctic species, not a Fennoscandian endemic. Rhabdomastix parva is a parthenogenetic species, males are unknown [101, 102]. The species is arctic, dwelling in northernmost Fennoscandia 
and Iceland. Evaluation of the status of the species is difficult because taxonomy of crane flies is heavily based on male genitalia. Molecular data and comparison with other Holarctic species would perhaps be fruitful in order to clarify the taxonomy of the species. Symplecta lindrothi is known from Sweden and Finland, in the latter country mainly around small lotic waters from south to north [56]. Due to its large range in Finland, it is perhaps a species occurring in but not yet collected from areas east of Fennoscandia. Tipula fendleri is known only from Finland, collected in the vicinity of springs and cold headwater streams [56]. Some of the collecting sites are very close to Sweden and Russia, thus the species is likely to be present also outside of the Finnish borders. The species may be a synonym of T. nigrolamina, a species known from Russian Far East [103] and Altay [104]. Finally, Cylindrotoma borealis, originally described as a subspecies of Holarctic C. distinctissima, is known from Norway, Finland, and Russian Karelia [105]. This is the only of the six Fennoscandian species discussed here that is hard to distinguish from its closest (sympatric) relative, in this case $C$. distinctissima. Based on mtDNA sequences (COI, ca. 658 base pairs), the species pair is separated by a distance of only ca. $0.5 \%$, a figure that is usually typical for intraspecific distances (e.g., [106]). It may be that $C$. borealis is an eastern haplotype within C. distinctissima (J. Salmela and N. Paramonov, in prep.), and these haplotypes ("borealis" and European $C$. distinctissima) occur in sympatry in Finland. To conclude, most of the Fennoscandian "endemic" crane flies are valid species, that is, there are no problems in their morphological identification from sympatric species. However, based on their current ranges in Finland, these species may well occur in Russia, but currently overlooked there (see summary in Table 5).

\section{Conclusions}

The current number of Finnish crane fly species is 335 . In practically all cases, the spatial scale being local or regional, the observed number of species is lower than estimated "true" richness (e.g., [107]). It is likely that there are crane fly species living within Finnish borders which are not yet collected and recorded. A total of 356 species are known from Sweden, a neighbor of Finland, and at least some Swedish (and Norwegian) species should occur in Finland too. However, geographic area of Sweden is larger than that of Finland, and it extends farther south than Finland, to the nemoral zone (more area, more heterogeneity $=$ more species). Despite the potential occurrence of undetected species, it may be concluded that the general trends reported here are most likely genuine and will not change if additional species are discovered.

Finnish crane fly fauna is strongly influenced by latitude. Thus, one may predict that both species composition and richness of local assemblages are in a large scale determined by geographical position alone. Local environmental factors, such as bedrock composition, vegetation type, and moisture then finally filter the inhabitants from the regional pool of species (e.g., [61]).

\section{Acknowledgments}

Comments by Jari Ilmonen, Liisa Puhakka, Ilari E. Sääksjärvi, David Roubik, and an anonymous referee improved the paper. Yuri Marusik helped the author with a text written in Russian. Thanks are due to all persons that have provided the author crane fly samples or occurrence data from Finland. The author also thanks Valentin Pilipenko for his notes on Tipula nigrolamina and Nikolay Paramonov for sharing his knowledge on Cylindrotoma distinctissima. This work was supported by grants from Finnish Cultural Foundation, Societas pro Fauna et Flora Fennica, Oskar Öflunds Stiftelse, and Societas Entomologica Helsingforsiensis.

\section{References}

[1] A. G. Fischer, "Latitudinal variations in organic diversity," Evolution, vol. 14, pp. 64-81, 1960.

[2] E. R. Pianka, "Latitudinal gradients in species diversity: a review of concepts," American Naturalist, vol. 100, pp. 33-46, 1966.

[3] K. J. Gaston, "Global patterns in biodiversity," Nature, vol. 405, no. 6783, pp. 220-227, 2000.

[4] M. Mönkkönen, J. T. Forsman, and F. Bokma, "Energy availability, abundance, energy-use and species richness in forest bird communities: a test of the species-energy theory," Global Ecology and Biogeography, vol. 15, no. 3, pp. 290-302, 2006.

[5] A. Clarke, "Climate and diversity: the role of history," in Scaling Biodiversity, D. Storch, P. A. Marquet, and J. H. Brown, Eds., pp. 225-245, Cambridge University Press, 2007.

[6] B. C. Cox and J. A. Moore, Biogeography. An Ecological and Evolutionary Approach, Blackwell Publishing, 7th edition, 2005.

[7] M. L. Rosenzweig, Species Diversity in Space and Time, Cambridge University Press, 1995.

[8] K. J. Gaston and T. Blackburn, Pattern and Process in Macroecology, Blackwell Science, 2000.

[9] M. Begon, J. L. Harper, and C. R. Townsend, Ecology. Individuals, populations and communities, Blackwell Science, Oxford, UK, 3rd edition, 1996.

[10] J. Kouki, P. Niemelä, and M. Viitasaari, "Reversed latitudinal gradient in species richness of sawflies (Hymenoptera, Symphyta)," Annales Zoologici Fennici, vol. 31, no. 1, pp. 83-88, 1994.

[11] A. F. G. Dixon, P. Kindlmann, J. Leps, and J. Holman, "Why there are so few species of aphids, especially in the tropics," American Naturalist, vol. 129, no. 4, pp. 580-592, 1987.

[12] A. Lillehammer, "Zoogeographical studies on Fennoscandian stoneflies ( Plecoptera)," Journal of Biogeography, vol. 12, no. 3, pp. 209-221, 1985.

[13] J. Heino, "Concordance of species richness patterns among multiple freshwater taxa: a regional perspective," Biodiversity and Conservation, vol. 11, no. 1, pp. 137-147, 2002.

[14] O. Järvinen and R. A. Väisänen, "Ecological zoogeography of North European waders, or why do so many waders breed in the North?" Oikos, vol. 30, pp. 495-507, 1978.

[15] O. Järvinen and L. Sammalisto, "Regional trends in the avifauna of Finnish peatland bogs," Annales Zoologici Fennici, vol. 13, pp. 31-43, 1976. 
[16] O. Järvinen, J. Kouki, and U. Häyrinen, "Reversed latitudinal gradients in total density and species richness of birds breeding on Finnish mires," Ornis Fennica, vol. 64, pp. 6773, 1987.

[17] J. Kouki, "Latitudinal gradients in species richness in northern areas: some exceptional patterns," Ecological Bulletins, vol. 47, pp. 30-37, 1999.

[18] D. H. Janzen, "The peak in North American ichneumonid species richness lies between $38^{\circ}$ and $42^{\circ} \mathrm{N}, "$ Ecology, vol. 62, pp. 532-537, 1981.

[19] P. Kindlmann, I. Schödelbauerová, and A. F. G. Dixon, "Inverse latitudinal gradients in species diversity," D. Storch, P. A. Marquet, and J. H. Brown, Eds., pp. 246-257, Scaling Biodiversity, Cambridge University Press, 2007.

[20] A. Veijalainen, I. E. Sääksjärvi, T. L. Erwin et al., "Subfamily composition of Ichneumonidae (Hymenoptera) from western Amazonia: insights into diversity of tropical parasitoid wasps," Insect Conservation and Diversity. In press.

[21] I. E. Sääksjärvi, S. Haataja, S. Neuvonen et al., "High local species richness of parasitic wasps (Hymenoptera: Ichneumonidae; Pimplinae and Rhyssinae) from the lowland rainforests of Peruvian Amazonia," Ecological Entomology, vol. 29, no. 6, pp. 735-743, 2004.

[22] D. L. J. Quicke, "We know too little about parasitoid wasp distributions to draw any conclusions about latitudinal trends in species richness, body size and biology," PLoS ONE, vol. 7, no. 2, Article ID e32101, 2012.

[23] A. Pekkarinen, "Views on the Late Weichselian and the early Holocene dispersal of insects and other biota in NW Europe," Norwegian Journal of Entomology, vol. 48, pp. 19-30, 2001.

[24] I. Nordal, "Tabula rasa after all? Botanical evidence for icefree refugia in Scandinavia reviewed," Journal of Biogeography, vol. 14, no. 4, pp. 377-388, 1987.

[25] C. H. Lindroth, "The theory of glacial refugia in scandinavia: comments in present opinions," Notulae Entomologicae, vol. 49, pp. 178-192, 1969.

[26] C. H. Lindroth, "Reflections on glacial refugia," Ambio Special Report, vol. 2, pp. 51-54, 1972.

[27] T. O. Vorren, K. D. Vorren, T. Alm, S. Gulliksen, and R. Lovlie, "The last deglaciation (20, 000 to 11, 000 B.P.) on Andoya, northern Norway," Boreas, vol. 17, no. 1, pp. 41-77, 1988.

[28] L. Brüstle and J. Muona, "Life-history studies versus genetic markers-the case of Hylochares cruentatus (Coleoptera, Eucnemidae)," Journal of Zoological Systematics and Evolutionary Research, vol. 47, no. 4, pp. 337-343, 2009.

[29] M. Carlsson, L. Söderberg, and H. Tegelström, "The genetic structure of adders (Vipera berus) in Fennoscandia: congruence between different kinds of genetic markers," Molecular Ecology, vol. 13, no. 10, pp. 3147-3152, 2004.

[30] G. M. Hewitt, "The structure of biodiversity-insights from molecular phylogeography," Frontiers in Zoology, vol. 1, article 4, 2004.

[31] T. Knopp and J. Merilä, "The postglacial recolonization of Northern Europe by Rana arvalis as revealed by microsatellite and mitochondrial DNA analyses," Heredity, vol. 102, no. 2, pp. 174-181, 2009.

[32] K. Mikkola, J. D. Lafontaine, and V. S. Kononenko, "Zoogeography of the Holarctic species of the Noctuidae (Lepidoptera): importance of the Beringian refuge," Entomologica Fennica, vol. 2, pp. 157-173, 1991.

[33] E. Hultén, Atlas Over Växternas Utbredning I Norden, Generalstabens Litografiska Anstalts Förlag, Stockholm, Sweden, 1950.
[34] M. Mönkkönen, "Diversity patterns in palaearctic and nearctic forest bird assemblages," Journal of Biogeography, vol. 21, no. 2, pp. 183-195, 1994.

[35] K. Mikkola, "Diversities and zoogeographic relationships of Noctuidae from the Northern Palaearctic: the Finnish fauna," in Proceedings of a Seminar International Moth Monitoring Scheme, M. Nieminen, Ed., vol. 630, pp. 8-12, TemaNord, 1996.

[36] A. J. Mela, Suomen Luurankoiset eli Luonnontieteellisen Suomen Luurankois-Eläimistö, K.E. Holm, Helsinki, Finland, 1882.

[37] O. Heikinheimo and M. Raatikainen, "Paikan ilmoittaminen Suomesta talletetuissa biologisissa aineistoissa," Annales Entomologici Fennici, vol. 37, pp. 1-27, 1971.

[38] Y. Vasari, "Edward Wainio-a pioneer of floristic research on the borderland between Northern Finland and Russian Karelia Biodiversity and conservation of boreal nature," in Proceedings of the 10 Years Anniversary Symposium of the Nature Reserve Friendship, R. Heikkilä and T. Lindholm, Eds., vol. 485, pp. 141-144, The Finnish Environment, 2003.

[39] R. Väisänen, K. Heliövaara, and A. Immonen, "Biogeography of northern European insects: province records in multivariate analyses (Saltatoria; Lepidoptera: Sesiidae; Coleoptera: Buprestidae, Cerambycidae)," Annales Zoologici Fennici, vol. 28, no. 2, pp. 57-81, 1991.

[40] T. Lahti, A. Kurtto, and R. A. Väisänen, "Floristic composition and regional species richness of vascular plants in Finland," Annales Botanici Fennici, vol. 25, no. 3, pp. 281291, 1988.

[41] R. Väisänen and K. Heliövaara, "Hot-spots of insect diversity in Northern Europe," Annales Zoologici Fennici, vol. 31, no. 1, pp. 71-81, 1994.

[42] J. Heino, T. Muotka, R. Paavola, H. Hämäläinen, and E. Koskenniemi, "Correspondence between regional delineations and spatial patterns in macroinvertebrate assemblages of boreal headwater streams," Journal of the North American Benthological Society, vol. 21, no. 3, pp. 397-413, 2002.

[43] J. Heino and H. Toivonen, "Aquatic plant biodiversity at high latitudes: patterns of richness and rarity in Finnish freshwater macrophytes," Boreal Environment Research, vol. 13, no. 1, pp. $1-14,2008$

[44] J. Ilmonen, L. Paasivirta, R. Virtanen, and T. Muotka, "Regional and local drivers of macroinvertebrate assemblages in boreal springs," Journal of Biogeography, vol. 36, no. 5, pp. 822-834, 2009.

[45] T. Ahti, L. Hämet-Ahti, and J. Jalas, "Vegetation zones and their sections in Northwestern Europe," Annales Botanici Fennici, vol. 5, pp. 169-211, 1968.

[46] B. Pedersen, "Distributional patterns of vascular plants in Fennoscandia: a numerical approach," Nordic Journal of Botany, vol. 10, no. 2, pp. 163-189, 1990.

[47] P. Oosterbroek, "Catalogue of the Craneflies of the World (Diptera, Tipuloidea: Pediciidae, Limoniidae, Cylindrotomidae, Tipulidae)," 2012, http://ip30.eti.uva.nl/ccw/index.php.

[48] C. P. Alexander, The Crane-Flies of New York. Part II. Biology and Phylogeny Memoirs, vol. 38, Cornell University Agricultural Experiment Station, 1920.

[49] A. Brindle, "The larvae and pupae of the British Cylindrotominae and Limoniinae," Transactions of the Society for British Entomology, vol. 17, pp. 151-216, 1967.

[50] F. Peus, "Cylindrotomidae," in Die Fliegen der Palaearktischen Region, E. Lindner, Ed., vol. 3, Lief. 169, pp. 1-80, 1952. 
[51] Y. I. Chernov and V. I. Lantsov, "Why do Tipulomorpha (Diptera, Insecta) succeed in the arctic conditions?" Acta Zoologica Cracoviensia, vol. 35, no. 1, pp. 193-197, 1992.

[52] S. F. MacLean, "Life cycle and growth energetics of the Arctic crane-fly Pedicia hannai antennata," Oikos, vol. 24, pp. 434443, 1973.

[53] M. J. Petersen, M. A. Bertone, B. M. Wiegmann, and G. W. Courtney, "Phylogenetic synthesis of morphological and molecular data reveals new insights into the higher-level classification of Tipuloidea (Diptera)," Systematic Entomology, vol. 35, pp. 526-545, 2010.

[54] B. M. Wiegmann, M. D. Trautwein, I. S. Winkler et al., "Episodic radiations in the fly tree of life," Proceedings of the National Academy of Sciences of the United States of America, vol. 108, no. 14, pp. 5690-5695, 2011.

[55] J. Starý, "Phylogeny and classification of Tipulomorpha, with special emphasis on the family Limoniidae," Acta Zoologica Cracoviensia, vol. 35, pp. 11-36, 1992.

[56] J. Salmela, "Annotated list of Finnish crane flies (Diptera: Limoniidae, Tipulidae, Pediciidae \& Cylindrotomidae)," Entomologica Fennica, vol. 22, pp. 219-242, 2011.

[57] O. Autio and J. Salmela, "A survey on the nematoceran (Diptera) communities of southern Finnish wetlands," Memoranda Societatis Pro Fauna et Flora Fennica, vol. 86, pp. 4353, 2010.

[58] J. Salmela, "Adult craneflies (Diptera: Nematocera) around springs in southern Finland," Entomologica Fennica, vol. 12, no. 3, pp. 139-152, 2001.

[59] J. Salmela, "Semiaquatic flies (Diptera, Nematocera) of three mires on the southern boreal zone, Finland," Memoranda Societatis Pro Fauna et Flora Fennica, vol. 80, no. 1, pp. 1-10, 2004.

[60] J. Salmela, "Semiaquatic fly (Diptera, Nematocera) fauna of fens, springs, headwater streams and alpine wetlands in the northern boreal ecoregion, Finland," W-Album, vol. 6, pp. 363, 2008.

[61] J. Salmela, "The semiaquatic nematoceran fly assemblages of three wetland habitats and concordance with plant species composition, a case study from subalpine Fennoscandia," Journal of Insect Science, vol. 11, article 35, 2011.

[62] J. Salmela and J. Ilmonen, "Cranefly (Diptera: Tipuloidea) fauna of a boreal mire system in relation to mire trophic status: implications for conservation and bioassessment," Journal of Insect Conservation, vol. 9, no. 2, pp. 85-94, 2005.

[63] J. Salmela, O. Autio, and J. Ilmonen, "A survey on the nematoceran (Diptera) communities of southern Finnish wetlands," Memoranda Societatis pro Fauna et Flora Fennica, vol. 83, no. 2, pp. 33-47, 2007.

[64] "Metsien suojelun tarve Etelä-Suomessa ja Pohjanmaalla. Etelä-Suomen ja Pohjanmaan metsien suojelun tarve työryhmän mietintö," in Suomen Ympäristö, R. Ruuhijärvi, M. Kuusinen, A. Raunio, and K. Eisto, Eds., vol. 437, pp. 1284, 2000.

[65] T. Lindholm and R. Heikkilä, Finland_Land of Mires, vol. 23, The Finnish Environment, Helsinki, Finland, 2006.

[66] E. B. Yakovlev, Palaearctic Diptera Associated with Fungi and Myxomycetes, Karelian Research Center, Russian Academy of Sciences, Petrozavodsk, Russian, 1994.

[67] G. E. Hancock, S. M. Hewitt, A. Godfrey et al., "Thoracic spiracular gill structure of Lipsothrix (Diptera, Limoniidae) in Britain described from scanning electron micrographs," Zoosymposia, vol. 3, pp. 77-87, 2009.
[68] N. P. Krivosheina and M. G. Krivosheina, Key to Terrestrial Crane-Fly Larvae (Diptera, Limoniidae, Pediciidae) of Russia, KMK Scientific Press, Moscow, Russia, 2011.

[69] V. E. Pilipenko, J. Salmela, and E. J. Vesterinen, "Description and DNA barcoding of Tipula (Pterelachisus) recondita sp. $\mathrm{n}$. from the Palaearctic region," ZooKeys, vol. 192, pp. 51-65, 2012.

[70] P. Legendre and L. Legendre, Numerical Ecology Developments in Environmental Modelling, vol. 20, Elsevier, 2nd edition, 1998.

[71] B. McCune and J. B. Grace, Analysis of Ecological Communities. With a Contribution from Dean L. Urban. MjM Software Design, Gleneden Beach, 2002.

[72] M. A. McGeoch and K. J. Gaston, "Occupancy frequency distributions: patterns, artefacts and mechanisms," Biological Reviews of the Cambridge Philosophical Society, vol. 77, no. 3, pp. 311-331, 2002.

[73] Ø. Hammer, D. A. T. Harper, and P. D. Ryan, "Past: paleontological statistics software package for education and data analysis," Palaeontologia Electronica, vol. 4, no. 1, pp. 19, 2001.

[74] O. Järvinen and R. A. Väisänen, "Species diversity of Finnish birds, I: zoogeographical zonation based on land birds," Ornis Fennica, vol. 50, pp. 93-125, 1973.

[75] J. A. Grytnes, H. J. B. Birks, and S. M. Peglar, "Plant species richness in Fennoscandia: evaluating the relative importance of climate and history," Nordic Journal of Botany, vol. 19, no. 4, pp. 489-503, 1999.

[76] J. Heino, "Regional gradient analysis of freshwater biota: do similar biogeographic patterns exist among multiple taxonomic groups?" Journal of Biogeography, vol. 28, no. 1, pp. 69-76, 2001.

[77] M. Luoto, R. K. Heikkinen, J. Pöyry, and K. Saarinen, "Determinants of the biogeographical distribution of butterflies in boreal regions," Journal of Biogeography, vol. 33, no. 10, pp. 1764-1778, 2006.

[78] E. Ranta and O. Järvinen, "Ecological biogeography: its history in Finland and recent trends," Annales Zoologici Fennici, vol. 24, no. 3, pp. 157-163, 1987.

[79] B. Mannheims, "Tipuliden und Limoniiden aus SüdwestHäme (Finnland)," Lounais-Hämeen Luonto, vol. 15, pp. 2022, 1964.

[80] B. Mannheims, "Sechzehn für Finnland neue Limoniiden mit liste der Tipulidae, Limoniidae, Cylindrotomidae, Liriopeidae, Trichoceridae und Phryneidae," Lounais-Hämeen Luonto, vol. 20, pp. 4-9, 1965.

[81] J. Viramo, "Koillismaan (Ks) vaaksiaisista (Diptera, Tipulidae)," Oulanka Reports, vol. 10, pp. 33-40, 1992.

[82] S. Koponen, Ed., "Invertebrates of Inari Lapland, Finland," Kevo Notes, vol. 7, pp. 67-69, 1984.

[83] R. L. H. Dennis and C. D. Thomas, "Bias in butterfly distribution maps: the influence of hot spots and recorder's home range," Journal of Insect Conservation, vol. 4, no. 2, pp. 73-77, 2000.

[84] H. V. Cornell and J. H. Lawton, "Species interactions, local and regional processes, and limits to the richness of ecological communities: a theoretical perspective," Journal of Animal Ecology, vol. 61, no. 1, pp. 1-12, 1992.

[85] J. Salmela, “Cranefly (Diptera: Tipuloidea \& Ptychopteridae) fauna of Limhamn limestone quarry (Sweden, Malmö) diversity and faunistics viewed from a NW European perspective," Norwegian Journal of Entomology, vol. 57, pp. 123135, 2010. 
[86] I. Hanski and O. Ovaskainen, "Extinction debt at extinction threshold," Conservation Biology, vol. 16, no. 3, pp. 666-673, 2002.

[87] J. Kouki, E. Hyvärinen, H. Lappalainen et al., "Landscape context affects the success of habitat restoration: large-scale colonization patterns of saproxylic and fire-associated species in boreal forests," Diversity and Distributions, vol. 18, pp. 348-355, 2012.

[88] S. Harrison, S. J. Ross, and J. H. Lawton, "Beta diversity on geographic gradients in Britain," Journal of Animal Ecology, vol. 61, no. 1, pp. 151-158, 1992.

[89] T. Tahvanainen, Diversity of water chemistry and vegetation of mires in the Kainuu region, middle boreal Finland. University of Joensuu [PhD Dissertations in Biology 33], Joensuu, Finland, 2005.

[90] K. J. Gaston and Rarity, Population and Community Biology Series, vol. 13, Chapman \& Hall, 1994.

[91] Y. Haila, O. Järvinen, and S. Raivio, "Quantitative versus qualitative distribution patterns of birds in the western Palearctic taiga," Annales Zoologici Fennici, vol. 24, no. 3, pp. 179-194, 1987.

[92] C. J. Krebs, Ecological Methodology, Addison Wesley Longman, 2nd edition, 1998.

[93] N. A. Campbell, J. B. Reece, and L. G. Mitchell, Biology, Benjamin/Cummins, Addison Wesley Longman, 5th edition, 1999.

[94] O. Järvinen and R. A. Väisänen, "Quantitative biogeography of Finnish land birds as compared with regionality in other taxa," Annales Zoologici Fennici, vol. 17, pp. 67-85, 1980.

[95] P. Oosterbroek, The Western Palaearctic Species of Nephrotoma Meigen, 1803 (Diptera, Tipulidae), Part 3, vol. 28 of Beaufortia, 1978.

[96] B. Theowald and P. Oosterbroek, "Zur Zoogeographie der westpalaearktischen Tipuliden, III. Die Tipuliden der europaischen Tiefebenen (Diptera, Tipulidae)," Bonner Zoologische Beitrage, vol. 34, pp. 371-394, 1983.

[97] B. Theowald and P. Oosterbroek, "Zur Zoogeographie der westpalaarktischen Tipuliden, VI. Die Tipuliden der montanen, alpinen und borealen Gebiete (Insecta, Diptera, Tipulidae)," Bonner Zoologische Beitrage, vol. 36, pp. 185220, 1985.

[98] E. N. Savchenko, "A species of Limoniid-flies (Diptera, Limoniidae) new for the fauna of the USSR, Limonia messaurea Mendl," Vestnik Zoologii, no. 6, p. 78, 1987 (Russian).

[99] H. Mendl, "A new Limonia from Swedish Lapland (Diptera, Tipulidae)," Entomologica Scandinavica, vol. 2, pp. 267-268, 1971.

[100] J. Salmela, "Revision of Tipula (Yamatotipula) stackelbergi Alexander (Diptera, Tipulidae), and a short discussion on subspecies among crane flies," ZooKeys, vol. 162, pp. 43-58, 2012.

[101] B. Tjeder, "Neuroptera, Trichoptera and Diptera-Tipulidae from Iceland with a redescription of Rhabdomastix parva Siebke," Opuscula Entomologica, vol. 29, pp. 143-151, 1964.

[102] J. Starý, "Revision of European species of the genus Rhabdomastix (Diptera: Limoniidae). Part I: introduction and subgenus Lurdia subgen. n," European Journal of Entomology, vol. 100, no. 4, pp. 587-608, 2003.

[103] C. P. Alexander, "Undescribed species of Japanese crane-flies (Diptera: Tipulidae). Part VII," Annals of the Entomological Society of America, vol. 43, pp. 418-436, 1950.
[104] V. E. Pilipenko, "New records of crane-flies (Diptera, Tipulidae) from Altai," Entomological Review, vol. 79, pp. 11781180, 1999.

[105] J. Salmela and O. Autio, "Semiaquatic flies of Kivineva mire, Middle boreal Finland, and redescription of Cylindrotoma borealis Peus, 1952 stat. n. (Diptera, Nematocera)," International Journal of Dipterological Research, vol. 18, pp. 47-55, 2007.

[106] A. Hausmann, G. Haszprunar, and P. D. N. Hebert, "DNA barcoding the geometrid fauna of Bavaria (Lepidoptera): successes, surprises, and questions," PLoS ONE, vol. 6, no. 2, Article ID e17134, 2011.

[107] A. E. Magurran, Measuring Biological Diversity, Blackwell Publishing, 2004. 

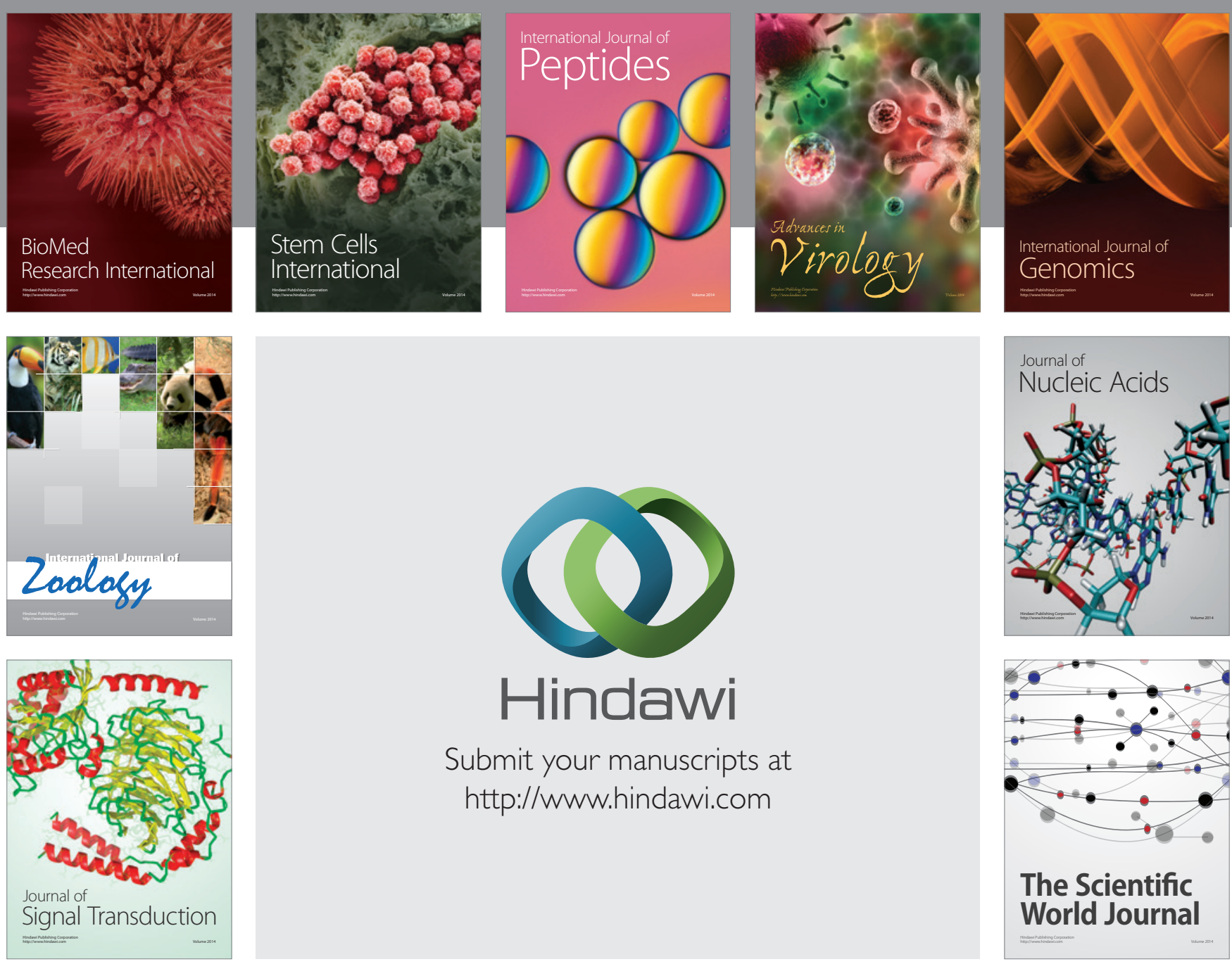

Submit your manuscripts at

http://www.hindawi.com
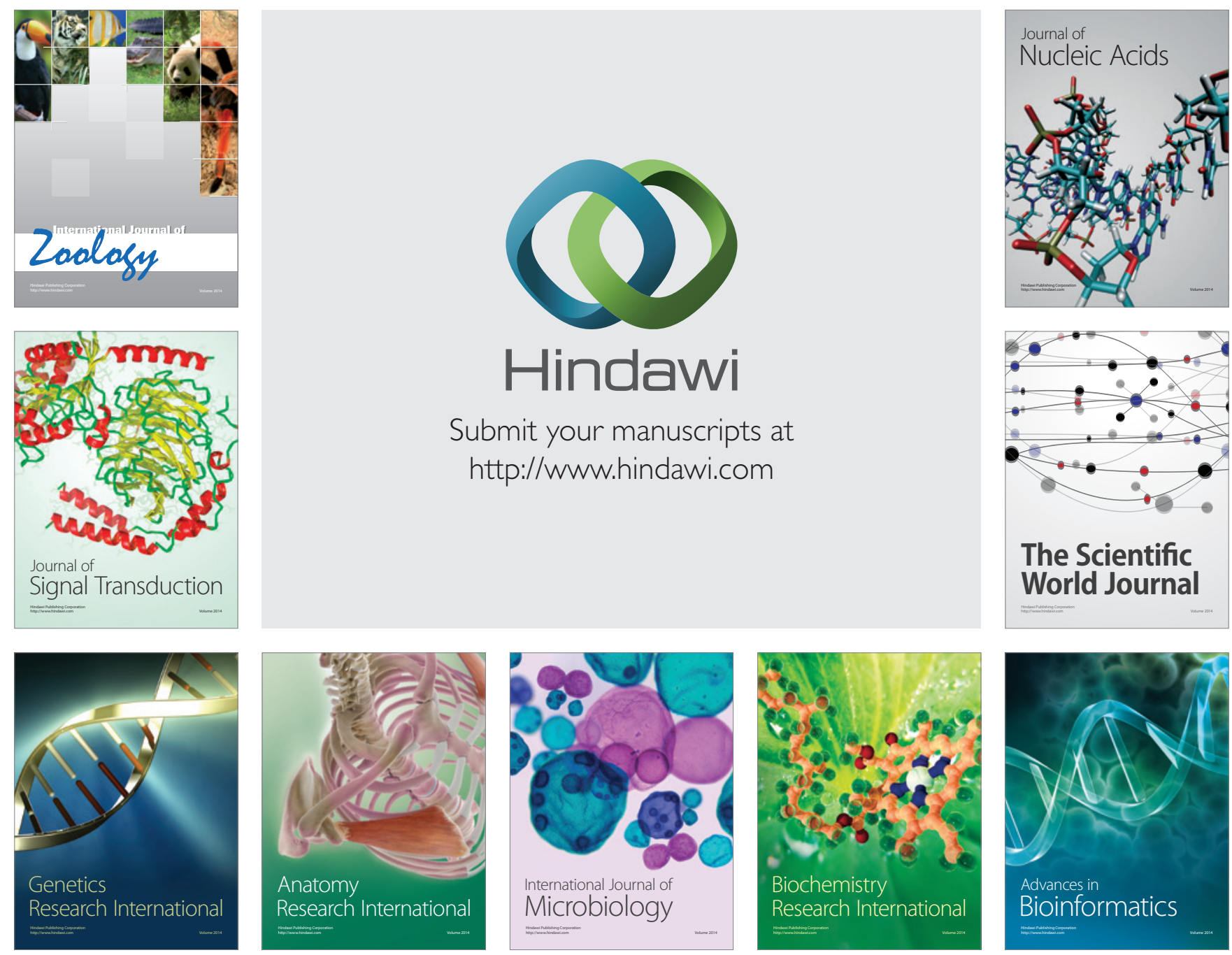

The Scientific World Journal
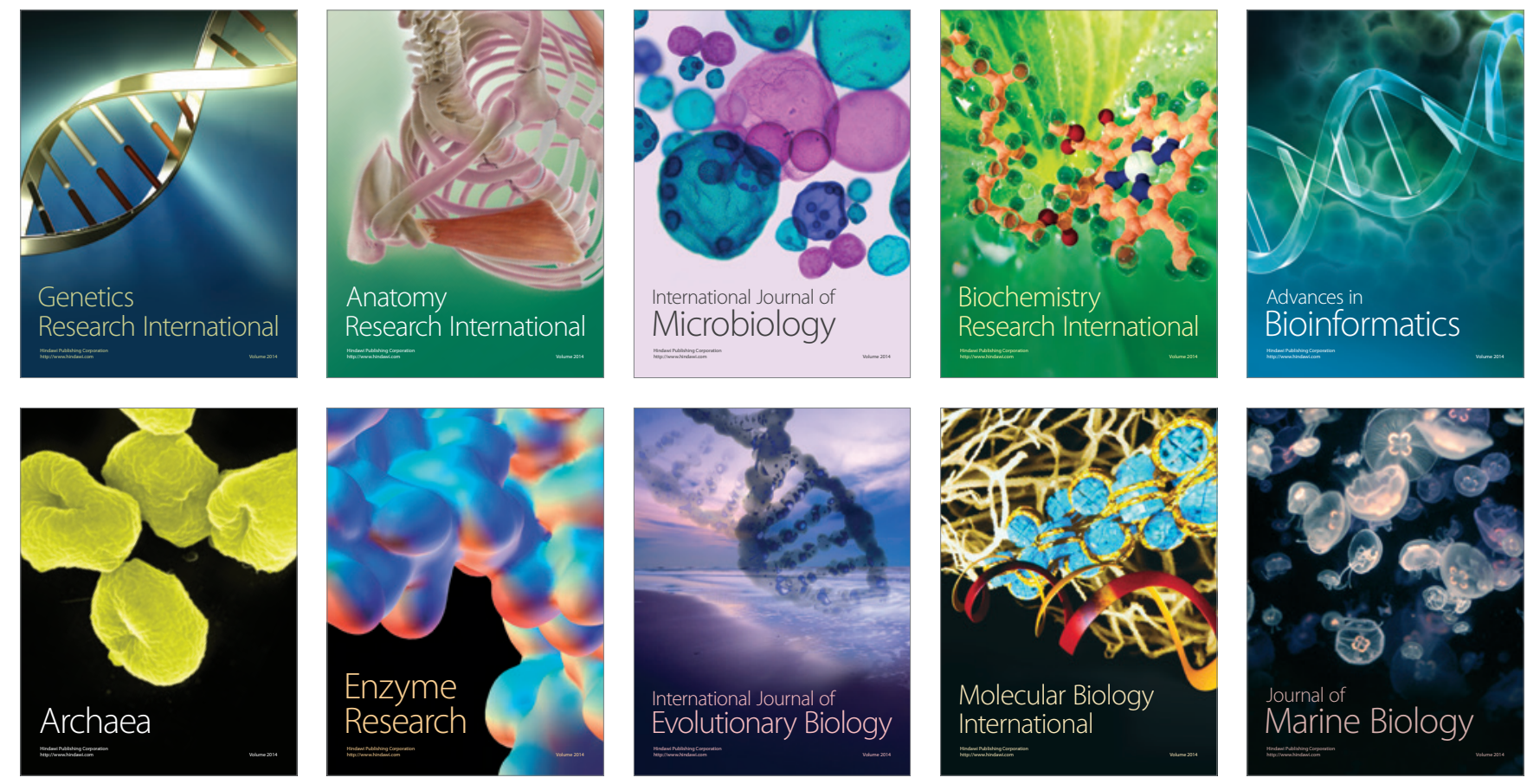